\title{
Neuroprotective effect of a new DJ-1-binding compound against neurodegeneration in Parkinson's disease and stroke model rats
}

\author{
Yoshihisa Kitamura', Shotaro Watanabe ${ }^{2}$, Masanobu Taguchi ${ }^{1}$, Kentaro Takagi ${ }^{1}$, Takuya Kawata', \\ Kazuko Takahashi-Niki ${ }^{4}$, Hiroyuki Yasui ${ }^{3}$, Hiroshi Maita ${ }^{4}$, Sanae MM Iguchi-Ariga ${ }^{2}$ and Hiroyoshi Ariga ${ }^{4 *}$
}

\begin{abstract}
Background: Parkinson's disease (PD) and cerebral ischemia are chronic and acute neurodegenerative diseases, respectively, and onsets of these diseases are thought to be induced at least by oxidative stress. PD is caused by decreased dopamine levels in the substantia nigra and striatum, and cerebral ischemia occurs as a result of local reduction or arrest of blood supply. Although a precursor of dopamine and inhibitors of dopamine degradation have been used for PD therapy and an anti-oxidant have been used for cerebral ischemia therapy, cell death progresses during treatment. Reagents that prevent oxidative stress-induced cell death are therefore necessary for fundamental therapies for PD and cerebral ischemia. DJ-1, a causative gene product of a familial form of PD, PARK7, plays roles in transcriptional regulation and anti-oxidative stress, and loss of its function is thought to result in the onset of PD. Superfluous oxidation of cysteine at amino acid 106 (C106) of DJ-1 renders DJ-1 inactive, and such oxidized DJ-1 has been observed in patients with the sporadic form of PD.
\end{abstract}

Results: In this study, a compound, comp-23, that binds to DJ-1 was isolated by virtual screening. Comp-23 prevented oxidative stress-induced death of SH-SY5Y cells and primary neuronal cells of the ventral mesencephalon but not that of DJ-1-knockdown SH-SY5Y cells, indicating that the effect of the compound is specific to DJ-1. Comp-23 inhibited the production of reactive oxygen species (ROS) induced by oxidative stress and prevented excess oxidation of DJ-1. Furthermore, comp-23 prevented dopaminergic cell death in the substantia nigra and restored movement abnormality in 6-hydroxyldopamine-injected and rotenone-treated PD model rats and mice. Comp-23 also reduced infarct size of cerebral ischemia in rats that had been induced by middle cerebral artery occlusion. Protective activity of comp-23 seemed to be stronger than that of previously identified compound B.

Conclusions: The results indicate that comp-23 exerts a neuroprotective effect by reducing ROS-mediated neuronal injury, suggesting that comp-23 becomes a lead compound for PD and ischemic neurodegeneration therapies.

\section{Background}

Parkinson's disease (PD) is a chronic neurodegenerative disease caused by dopaminergic cell death, and genetic and environmental factors are thought to affect the onset of PD. Cerebral infarction and stroke are acute neurodegenerative diseases caused by ischemic injury. Onsets of these diseases are thought be induced at least

\footnotetext{
* Correspondence: hiro@pharm.hokudai.ac.jp

${ }^{4}$ Graduate School of Pharmaceutical Sciences, Hokkaido University, Sapporo, Japan

Full list of author information is available at the end of the article
}

by oxidative stress, but the precise mechanisms are still not known. Although a precursor of dopamine, inhibitors of dopamine degradation and dopamine releasers have been used for PD therapy and an anti-oxidant have been used for cerebral infarction and stroke, cell death progresses during treatment. Identification of compounds or proteins that inhibit oxidative stress-induced neuronal cell death is necessary.

DJ-1 was first identified by our group as a novel oncogene product [1] and later found to be a causative gene product of a familial form of PD, PARK7 [2]. DJ-1 plays

\section{() Biomed Central}


roles in transcriptional regulation [3-9] and anti-oxidative stress reaction [10-13], and loss of its function is thought to result in the onset of PD. DJ-1 has three cysteines at amino acid numbers 46, 53, and 106 (C46, C53, and C106, respectively). Although oxidation of C106 is necessary for DJ-1 to exert its activity [12-15], further oxidation of C106 is thought to render DJ-1 inactive [16,17], and such oxidized DJ-1 has been observed in patients with the sporadic form of PD and Alzheimer disease [18,19].

We have shown that administration of DJ-1 protein dramatically reduced dopaminergic cell death and restored locomotion defect in PD model rats into which 6-hydroxydopamine (6-OHDA) had been injected [20] and that intrastriatal injection of DJ-1 markedly reduced infarct size in cerebral ischemia in rats [21], suggesting that DJ-1 is a pharmaceutical target for PD and cerebral ischemia. Another group also reported protective activity of DJ-1 against stroke [22]. Furthermore, we identified compounds that bind to the C106 region of DJ-1, and these compounds including compounds A and B, like DJ-1 protein, prevented oxidative stress-induced dopaminergic cell death and restored locomotion defect in PD model rats and also reduced infarct size in cerebral ischemia in rats [23-25]. These compounds were found by screening the University Compound library, which contains approximately 30,000 compounds.

In this study, we further screened DJ-1-binding compounds from the Zinc compound library that contains approximately 2,500,000 compounds. Of the compounds identified, compound-23 (comp-23) protected oxidative stress-induced cell death both in cultured cells and in PD and ischemia model rats and mice, and the protective activity of comp-23 seemed to be stronger than that of compound $\mathrm{B}$.

\section{Results}

\section{Isolation of a DJ-1-binding compound}

We have previously reported the isolation of DJ-1-binding compounds in silico using a Fujitsu Bioserver from a compound library, which is organized by the University Compound Project at the Foundation for Education of Science and Technology and contains approximately 30,000 compounds [23]. Based on the X-ray crystal structures of DJ-1 [26,27], compounds binding to the C106 region of DJ-1 were identified. In this study, we screened DJ-1-binding compounds in silico from the Zinc compound library that contains approximately $2,500,000$ compounds using the same method as that described previously [23]. Twenty-five compounds whose docking score toward DJ-1 was less than -100 $\mathrm{Kcal} /$ mole were obtained. The effects of candidate compounds on oxidative stress-induced cell death were examined. Human dopaminergic neuroblastoma cell line
SH-SY5Y cells were incubated with $1 \mu \mathrm{M}$ of each compound for 20 hours and then treated with $400 \mu \mathrm{M}$ $\mathrm{H}_{2} \mathrm{O}_{2}$ for 3 hours, and cell viability was measured by an MTT assay (Figure 1A). Results of some compounds were shown. Cell death induced by addition of $\mathrm{H}_{2} \mathrm{O}_{2}$ was significantly inhibited only by addition of compound-23 (comp-23) under this condition, and the other compounds, including compound B (comp-B) that was reported previously [23], had a little effect against cell death induced by less than $400 \mu \mathrm{M} \mathrm{H}_{2} \mathrm{O}_{2}$. Therefore, we concentrated on analyses of comp-23 in further study. Structures of comp-23 and comp-B are shown in Figure 1B.

Binding of comp-23 to DJ-1 was confirmed by using a quartz crystal microbalance in which compound-23, compound D (Figure 1B) or bovine serum albumin (BSA) was fixed on a sensor chip and recombinant DJ-1 was applied. Compound D is a negative control compound whose docking score toward DJ-1 was more than $+200 \mathrm{Kcal} / \mathrm{mole}$. As shown in Figure 1C, comp-23 bound to DJ-1, and compound D and BSA hardly bound to DJ-1. The binding constant $(\mathrm{Kd})$ of comp-23 to DJ-1 is calculated to be $1.03 \times 10^{-7} \mathrm{M}$.

\section{Effects of DJ-1-binding compound-23 on oxidative stress- induced cell death and ROS production}

The effect of comp-23 on oxidative stress-induced cell death was examined. SH-SY5Y cells were incubated with $1 \mu \mathrm{M}$ comp-23 for 20 hours and then treated with $250 \mu \mathrm{M} \mathrm{H} \mathrm{H}_{2} \mathrm{O}_{2}$ for 24 hours or $450 \mu \mathrm{M} \mathrm{H} \mathrm{H}_{2} \mathrm{O}_{2}$ for 3 hours or with $50 \mu \mathrm{M} 6$-OHDA for 24 hours or $125 \mu \mathrm{M}$ 6-OHDA for 1 hour, and cell viability was measured by an MTT assay (Figures 2A-D). Without the compound, $90-70 \%$ of the cells died and vehicle (DMSO) control of cells had little effect on protection against cell death. With comp-23, on the other hand, cell death induced by addition of $\mathrm{H}_{2} \mathrm{O}_{2}$ or 6-OHDA was significantly inhibited. Compound D had little effect. It should be noted that comp-23 at doses used in this study had no toxicity against culture cells.

The effect of comp-23 on production of reactive oxygen species (ROS) was then examined. SH-SY5Y cells were pretreated with $1 \mu \mathrm{M}$ comp-23 for 20 hours and then treated with DCFA-DA and exposed to $40 \mu \mathrm{M}$ 6-OHDA for $10 \mathrm{~min}$. ROS were then measured by using a fluorescence spectrophotometer. As shown in Figure 2E, comp-23, but not comp-D, significantly reduced the level of ROS in cells that had been treated with 6-OHDA compared to that in vehicle-control cells.

Primary neuronal cells of the ventral mesencephalon were prepared from rat embryos on the 17-19th days of gestation. To examine the presence of dopaminergic neurons in cell culture, cells were immunostained using anti-NeuN and anti-TH antibodies to identify all of the 


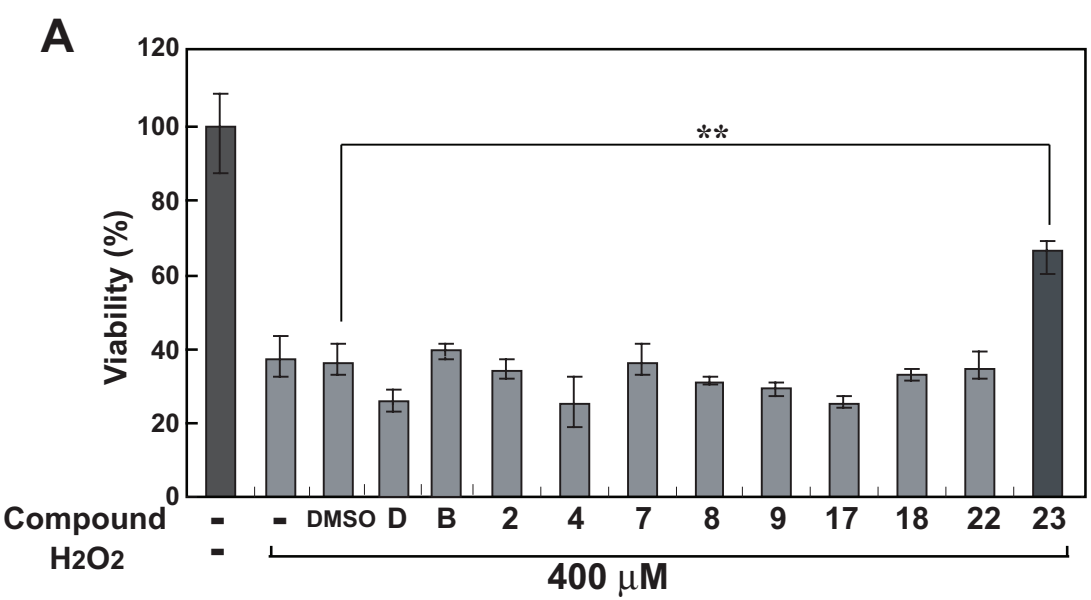

B<smiles>COc1cc(C(=O)Nc2ccc(-c3cn4cccc(C)c4n3)cc2)cc(OC)c1OC</smiles>

\section{Comp-23}<smiles>O=c1[nH]cnc2[nH]cnc12</smiles>

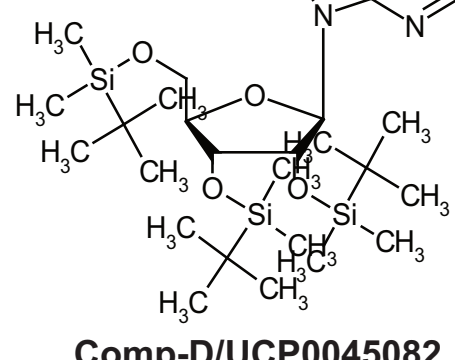<smiles>CCC(=O)NCCc1cc(OC)c2c(c1)OCO2</smiles><smiles>CCc1ccc(OC)c(OCc2ccccc2)c1</smiles>

\section{Comp-B/UCP0054278}

C
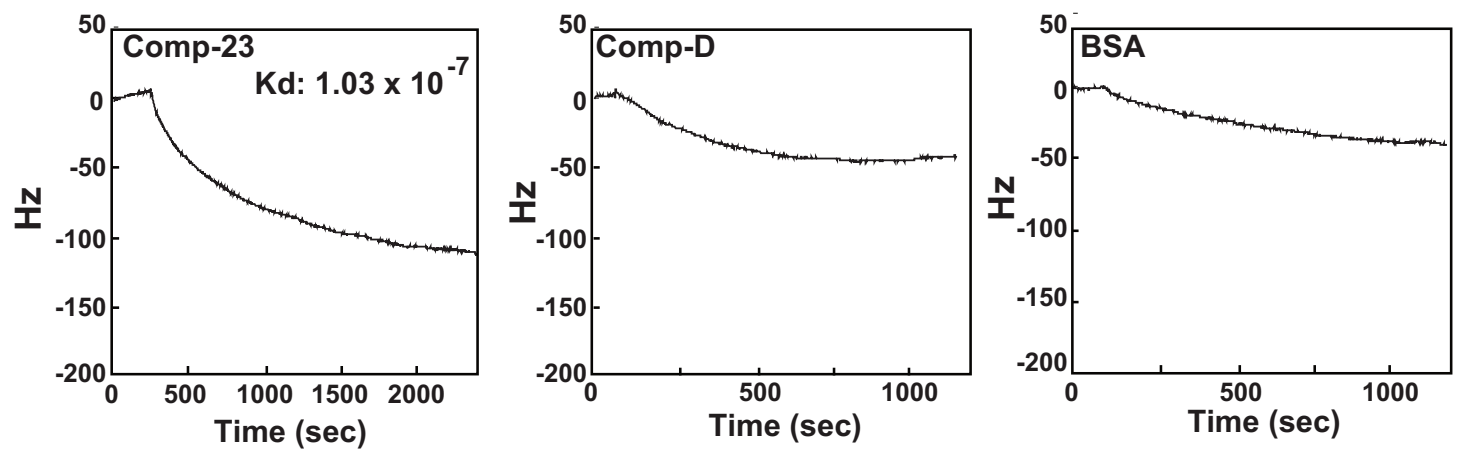

Figure 1 Identification of DJ-1-binding compounds and effects of DJ-1-binding compounds on oxidative stress-induced cell death (A) SH-SY5Y cells were pretreated with $1 \mu \mathrm{M}$ of each compound for 20 hours and then treated with $\mathrm{H}_{2} \mathrm{O}_{2}$ for 3 hours, and cell viability was measured by an MTT assay. "-" indicates cells not treated with compounds. Significance: ** $P<0.01$ versus vehicle (DMSO) control without compounds. (B) Chemical structures of compound-23, -B and -D. (C) Binding of compounds to DJ-1 was examined by using a quartz crystal microbalance as described in Methods. Hz indicates decreased frequency of a sensor chip. 


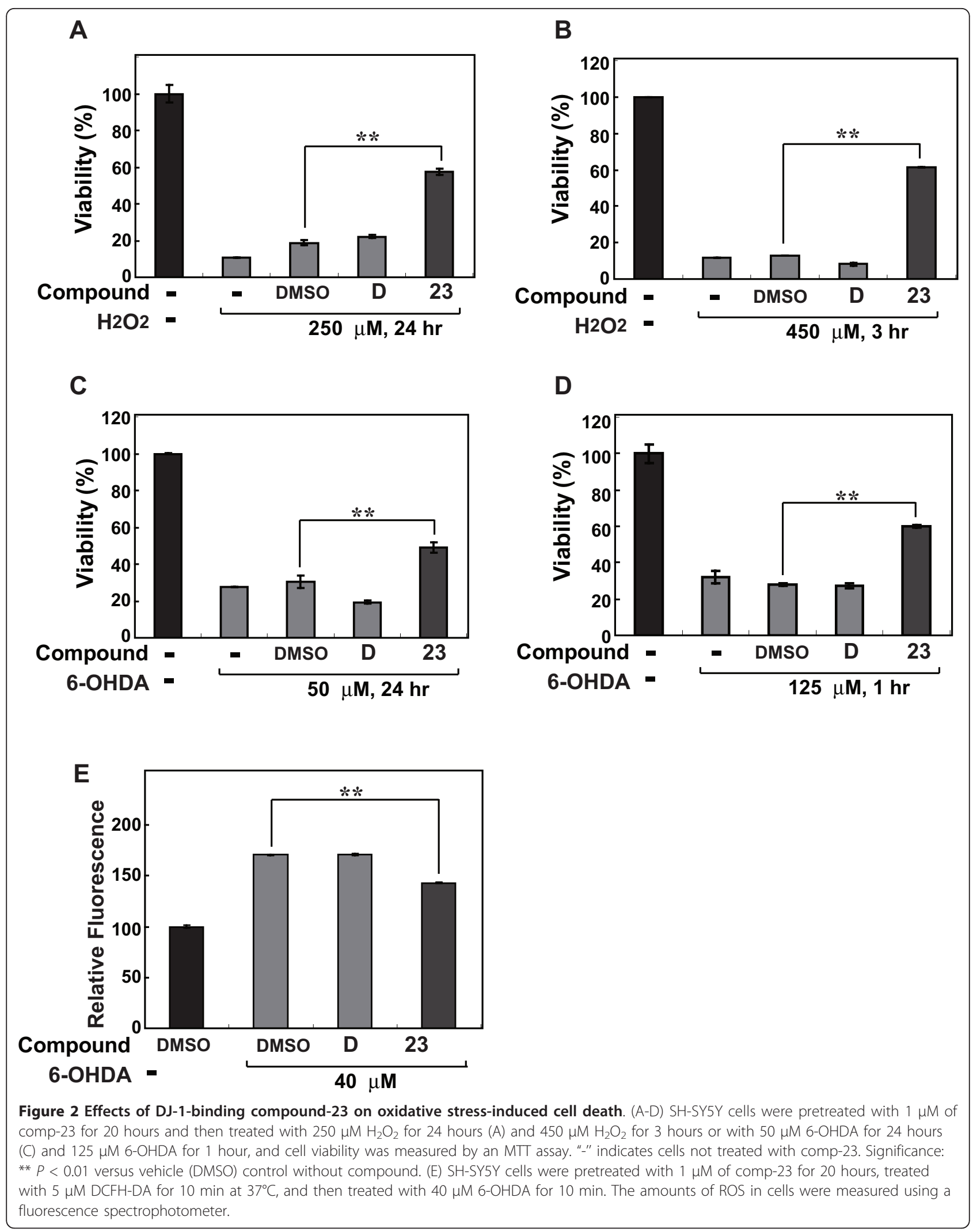


neurons and dopaminergic neurons, respectively, and cell nuclei were stained with DAPI. Primary neuronal cells were pretreated with $1 \mu \mathrm{M}$ comp-23 for 20 hours and then treated with $200 \mu \mathrm{M} \mathrm{H}_{2} \mathrm{O}_{2}$ for 3 hours. The results showed that comp-23, but not comp-D, significantly reduced cell death (Figure 3B).

\section{DJ-1-specific reaction of compound-23}

To know the specificity of comp-23 to DJ-1, the effect of comp-23 on oxidative stress-induced cell death was examined using DJ-1-knockdown SHSY5Y cells (KDSH-SY5Y cells) that had been established previously [15]. The expression levels of DJ-1 in KD-SH-SY5Y cells and parental SH-SY5Y cells (host) were examined by Western blotting with an anti-DJ-1 antibody and quantified by normalization of the level of DJ-1 compared to that of $\beta$-actin (Figure $4 \mathrm{~A}$ ). The results showed that about $60 \%$ of DJ-1 expression was knocked down in
KD-SH-SY5Y cells. When SH-SY5Y and KD-SH-SY5Y cells were treated with $100 \mu \mathrm{M} \mathrm{H}_{2} \mathrm{O}_{2}$ for 3 hours, about $25 \%$ and $98 \%$ of the cells, respectively, died (Figures 3B and $3 \mathrm{C}$ ), confirming that DJ-1-knockdown cells are more susceptible to oxidative stress than are parental cells as described previously $[10,12,13,15]$. Pretreatment of cells with com-23 for 20 hours before the addition of various concentrations of $\mathrm{H}_{2} \mathrm{O}_{2}$ significantly abrogated cell death of parental SH-SY5Y cells but not that of KDSH-SY5Y cells (Figures 3B and 3C). These results clearly indicate that DJ-1-binding compound-23 functions in a DJ-1-dependent manner and that there is a threshold amount of DJ-1 for DJ-1-binding compounds to function in cells.

\section{Lack of scavenging activity for hydroxyl radical $(\cdot \mathrm{OH})$}

Recent studies suggest that $\mathrm{H}_{2} \mathrm{O}_{2}$ is produced by mitochondrial dysfunction or autoxidation of dopamine and

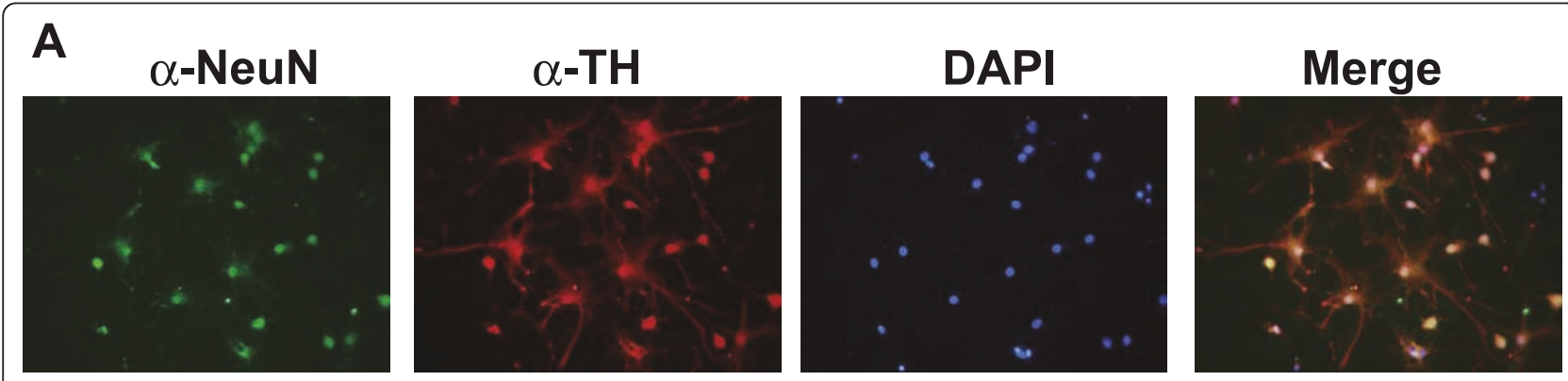

B

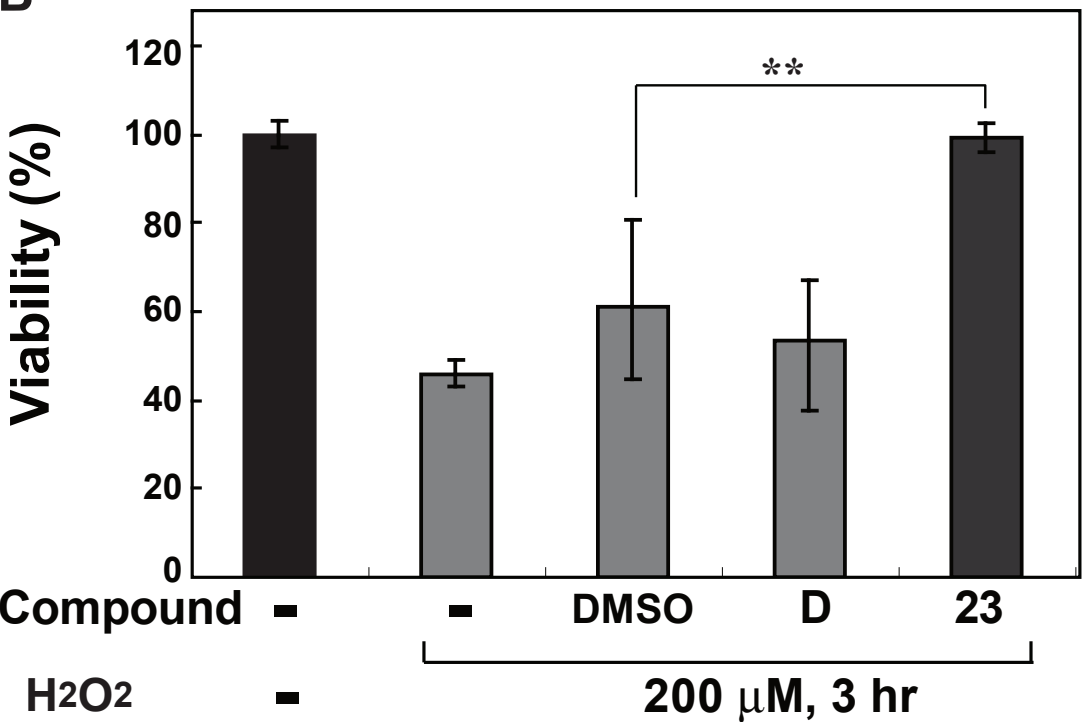

Figure 3 Effects of compound-23 on oxidative stress-induced death of rat mesencephalic neurons. (A) Rat mesencephalic cultured neurons were fixed and immunostained by anti-NeuN and anti-TH antibodies. Cells were then stained with DAPI. The cells were then reacted with a rhodamine-conjugated anti-rabbit lgG or fluorescein isothiocyanate-conjugated anti-mouse lgG and observed under an All-in-on microscope. (B) Rat mesencephalic cultured neurons were treated with $1 \mu \mathrm{M}$ of comp-23 for 20 hours and with $200 \mu \mathrm{M} \mathrm{H} \mathrm{H}_{2}$ for 3 hours, and cell viability was measured by an MTT assay. Significance: ${ }^{* *} P<0.01$ versus vehicle (DMSO) control without compound. 


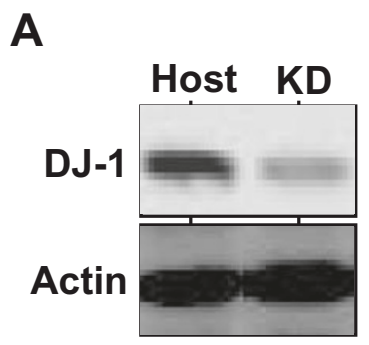

B. Host

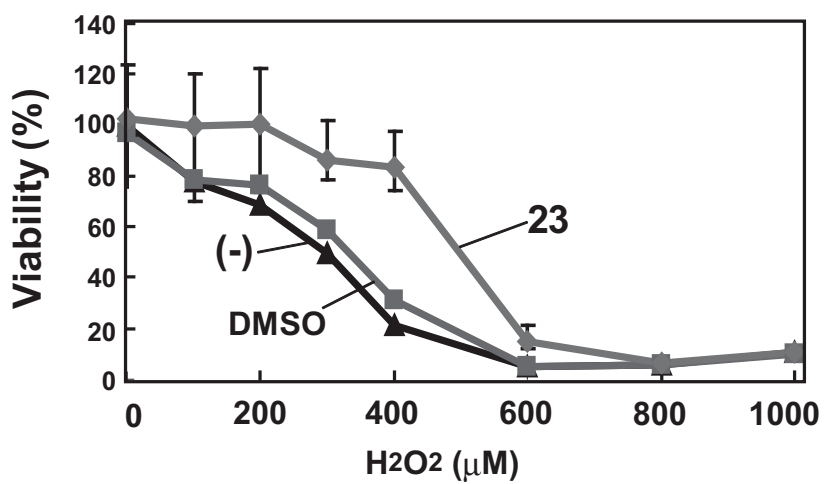

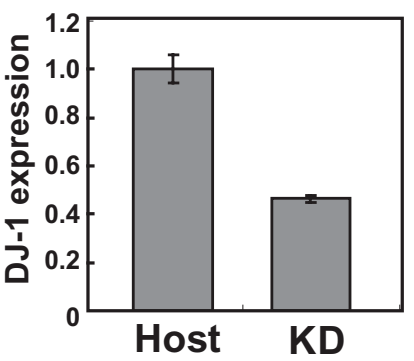

C. Knockdown

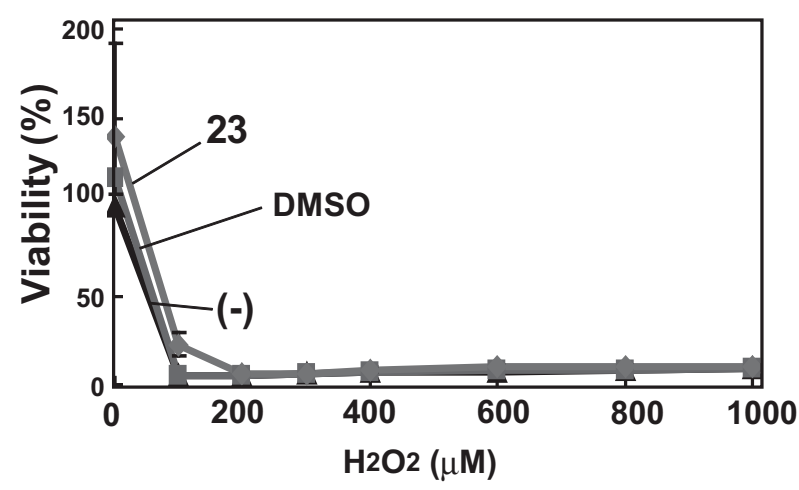

Figure 4 DJ-1-specific action of DJ-1-binding compound-23. (A) Cell extracts were prepared from SH-SY5Y and KD-SH-SY5Y cells, and proteins in the extracts were analyzed by Western blotting with anti-DJ-1 and anti-actin antibodies. After membranes had been reacted with respective secondary antibodies, bands were visualized and their intensities were quantified using an infrared imaging system (Odyssey, LI-COR). ( $\mathrm{B}$ and C) SH-SY5Y (B) and KD-SH-SY5Y (C) cells were treated with $1 \mu \mathrm{M}$ of comp-23 for 20 hours and with various concentrations of $\mathrm{H}_{2} \mathrm{O}_{2}$ for 3 hours, and cell viability was measured by an MTT assay.

6-OHDA, and then $\mathrm{OH}$ is easily generated in the presence of $\mathrm{Fe}^{2+}[28,29]$. It is known that $\mathrm{OH}$ is one of most potent neurotoxic factors in dopaminergic neurodegeneration. To clarify whether comp-23 can directly scavenge $\mathrm{OH}$, we further performed electron spin resonance (ESR) analysis using a spin trapper, 5,5-dimethyl1 -pyrroline- $N$-oxide (DMPO). As an internal reference, $\mathrm{Mn}^{2+}$ signal was detected as two small peaks at both edges (Figure 5A, Control). Although no marked signal was detected in the absence of $\mathrm{Fe}^{2+}$, four major peaks with an intensity ratio of $1: 2: 2: 1$ appeared at the midsection between the $\mathrm{Mn}^{2+}$ signal in the presence of $\mathrm{H}_{2} \mathrm{O}_{2}$ and $\mathrm{Fe}^{2+}$ (Figure $5 \mathrm{~A}, \mathrm{H}_{2} \mathrm{O}_{2}$ ). This characteristic quartet signal was almost completely suppressed by thiourea (Figure $5 \mathrm{~A}, \mathrm{H}_{2} \mathrm{O}_{2}+$ thiourea), a specific $\mathrm{OH}$ scavenger, suggesting that the quartet signal indicates DMPO-OH spin adduct. In contrast, $\mathrm{H}_{2} \mathrm{O}_{2}$-induced DMPO-OH signal could not be reduced by comp-23 even at a high concentration of $100 \mu \mathrm{M}$ (Figure 5A). These results indicate that comp-23 is not a simple anti-oxidant.
Effects of compound-23 on oxidation and dimer formation of DJ-1

We have reported that comp-B prevented excess oxidation of DJ-1 in cells that had been treated with $\mathrm{H}_{2} \mathrm{O}_{2}$ or 6-OHDA [23]. To examine whether this is true for comp-23, SH-SY5Y cells were first incubated with comp-23 or comp-B for 20 hours and treated with various amounts of $\mathrm{H}_{2} \mathrm{O}_{2}$. Oxidation of DJ-1 was analyzed by isoelectric focusing. As shown in Figure 6A, reduced and oxidized forms of DJ-1 were observed in cells in the absence of $\mathrm{H}_{2} \mathrm{O}_{2}$. After cells were treated with $\mathrm{H}_{2} \mathrm{O}_{2}$, the level of oxidized DJ-1 increased in cells that had not been treated with compound. No or little increase of the oxidized DJ-1 level was, on the other hand, observed in cells that had been incubated with comp-23 or with comp- $\mathrm{B}$, indicating that comp-23, like comp-B, prevents excess oxidation of DJ-1.

Since DJ-1 works as dimer, the effect of comp-23 on dimer formation of DJ-1 was examined. SY-SY5Y cells were incubated with $1 \mu \mathrm{M}$ comp-23 or with $1 \mu \mathrm{M}$ comp-B for 20 hours, treated with various amounts of 


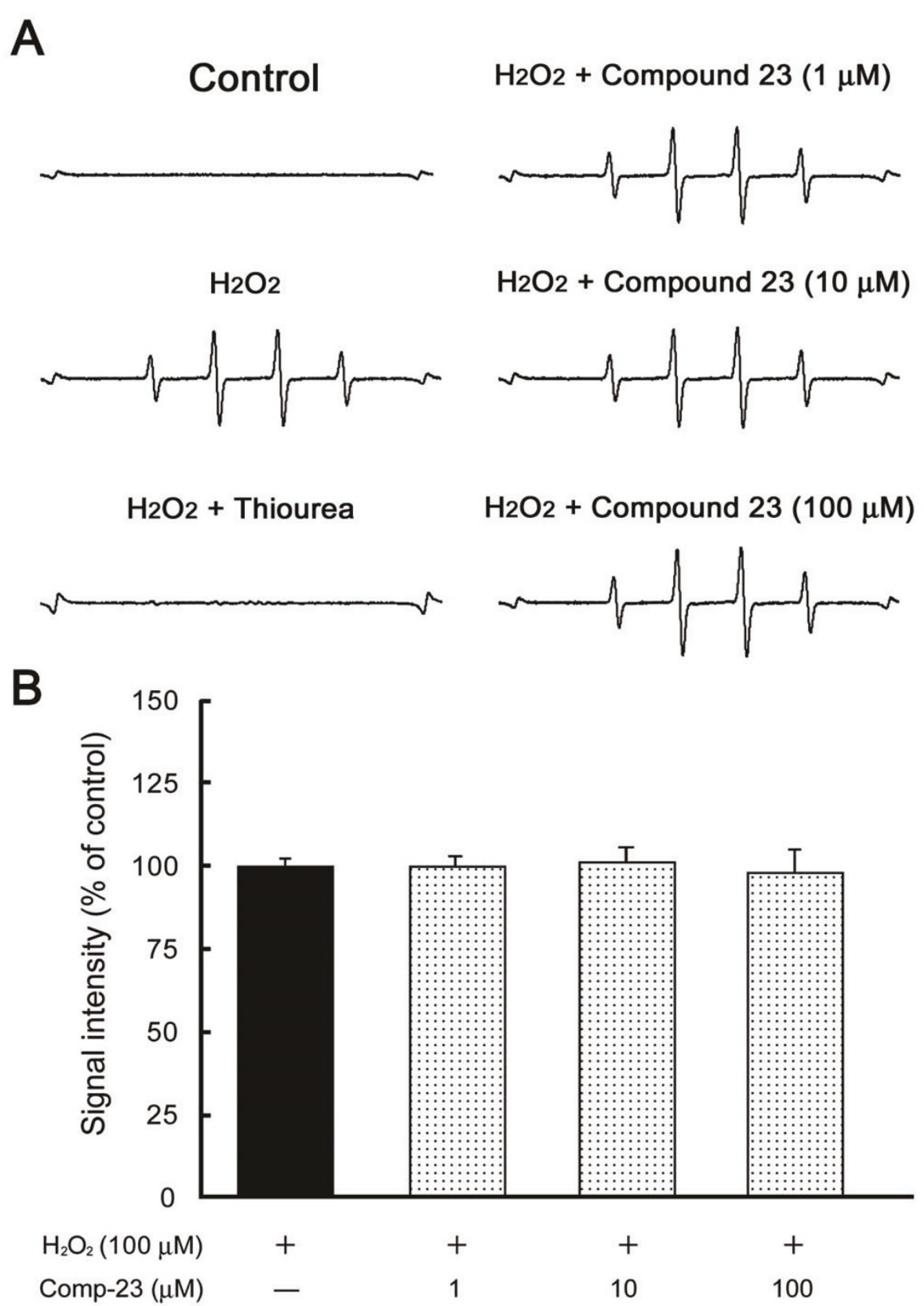

Figure 5 ESR analysis. (A) Typical ESR spectra of DMPO-OH spin adducts in the control (without $\left.\mathrm{H}_{2} \mathrm{O}_{2}\right), 100 \mu \mathrm{M} \mathrm{H} \mathrm{H}_{2} \mathrm{O}_{2}\left(\right.$ with $25 \mu \mathrm{M} \mathrm{Fe}{ }^{2+}$ ), $\mathrm{H}_{2} \mathrm{O}_{2}$ (with $\mathrm{Fe}^{2+}$ ) $+500 \mathrm{mM}$ thiourea, and $\mathrm{H}_{2} \mathrm{O}_{2}$ (with $\mathrm{Fe}^{2+}$ ) + comp-23 at 1, 10 and $100 \mu \mathrm{M}$. (B) Semi-quantitative measurement of in vitro $\mathrm{OH}$ generation. Each value is the mean $\pm \mathrm{SEM}$ of eight determinations, based on $\mathrm{H}_{2} \mathrm{O}_{2} / \mathrm{Fe}^{2+}$ as $100 \%$. 


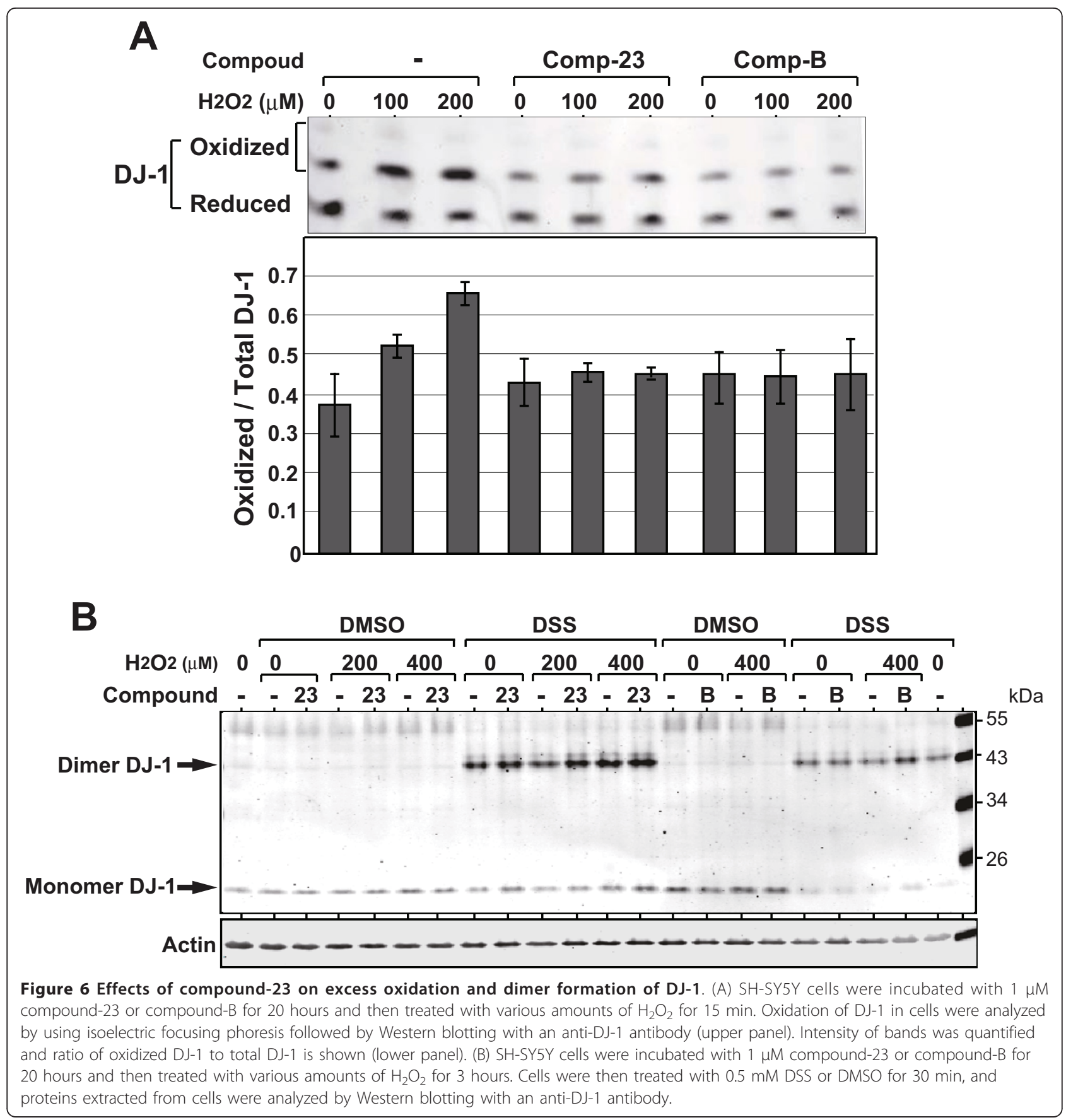

$\mathrm{H}_{2} \mathrm{O}_{2}$ for 3 hours and then treated with disuccinimidyl suberate (DSS) or with dimethyl sulfoxide (DMSO) as a vehicle control. Proteins extracted from cells were analyzed by Western blotting with an anti-DJ-1 antibody (Figure 6B). The results showed that the levels of dimmer DJ-1 observed in DSS-treated cells were not changed in the presence or absence of DJ-1-binding compounds, indicating that both comp- 23 and comp-B do not affect dimer formation of DJ-1.
Effects of compound-23 on oxidative stress-induced cell death and movement defect in Parkinson's disease model rats

To examine the effect of DJ-1-binding comp-23 on PD phenotypes in vivo, we used PD model rats in which 6-OHDA was stereotaxically microinjected into the unilateral (left) mesencephalon. Administration of methamphetamine to animals induced movement ipsilateral to the injection site, and the rotational behavior was significantly 
reduced by coadministration of comp-23 at 7 days after injection (Figure 7). The total number of rotations of rats (Figure 7A) and number of rotations during the course of administration of methamphetamine (Figure 7B) were significantly reduced. As shown in Figure 8A, TH-immunopositive neurons were obviously preserved in the ipsilateral substantia nigra pars compacta (SNpc) of comp23-treated animals compared to those in animals injected with 6-OHDA alone at 10 days post-lesion. Semi-quantitative analysis of nigral $\mathrm{TH}$-immunopositive neurons showed that while microinjection of 6-OHDA alone caused a significant loss of dopaminergic neurons $(5 \pm 2 \%$ survival rate), loss of dopaminergic neurons was significantly inhibited by simultaneous administration of comp$23(60 \pm 13 \%)$ (Figure 8B). Comp-23 alone did not affect $\mathrm{TH}$-immunoreactivity in the Snpc that had not been injected with 6-OHDA (Figure 8). In the ipsilateral striatum, although $\mathrm{TH}$ immunoreactivity almost completely disappeared in rats injected with 6-OHDA alone, TH immunoreactivity was restored by coadministration of comp-23 (Figure 9A). The intensity of TH-immunoreactivity in the striatal quadrants, including the dorsal, medial, lateral and ventral parts (Figure 9B), was significantly increased in comp-23-treated animals compared to the intensity in 6-OHDA-treated animals (Figure 9C).

Effect of compound-23 on infarct size in focal cerebral ischemia and reperfusion in rats in a dose-dependent manner

Comp-23 was microinjected intrastriatally into the left striatum of rats, and left middle cerebral artery occlusion (MCAO) for $90 \mathrm{~min}$ and reperfusion were performed at $30 \mathrm{~min}$ after microinjection of comp-23. As shown in Figure 10A, although a marked regional loss of 2,3,5-triphenyltetrazolium chloride (TTC)-staining occurred in the ipsilateral cerebral cortex and striatum in vehicle-injected rats at 24 hours after MCAO, the area of TTC staining lost was smaller with microinjection of comp-23. In quantitative analysis, each infarct area was smaller and the total infarct volume was significantly reduced by the administration of comp-23 compared with that in vehicle-injected rats (Figures $10 \mathrm{~B}$ and 10C). Thus, comp-23 exhibits neuroprotective effects by direct microinjection into the striatum of brain ischemic rats (Figure 10). Therefore, we further examined whether or not peripheral administration of comp-23 induces neuroprotection. Before and after 120-min MCAO, rats were intraperitoneally administered comp23. Subsequently, we assessed the neuroprotective effect. As shown in Figure 11, focal ischemia-induced neurodegeneration was also prevented by peripheral administration of comp-23 in a dose-dependent manner. These results indicate that comp-23 has neuroprotective activity against oxidative stress-induced stroke and Parkinson's disease model rats.

\section{Effect of peripheral administration of compound-23 on rotenone-induced movement dysfunction in mice} Although 6-OHDA-microinhected rat PD model is useful in pharmacological screening of drugs, the bloodbrain barrier (BBB) is broken by the direct microinjection into the substantia nigra (ventral mesencephalon).
A

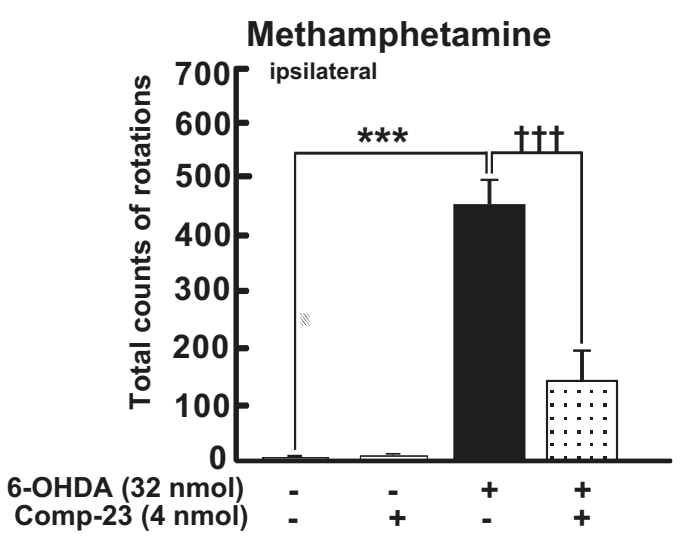

B

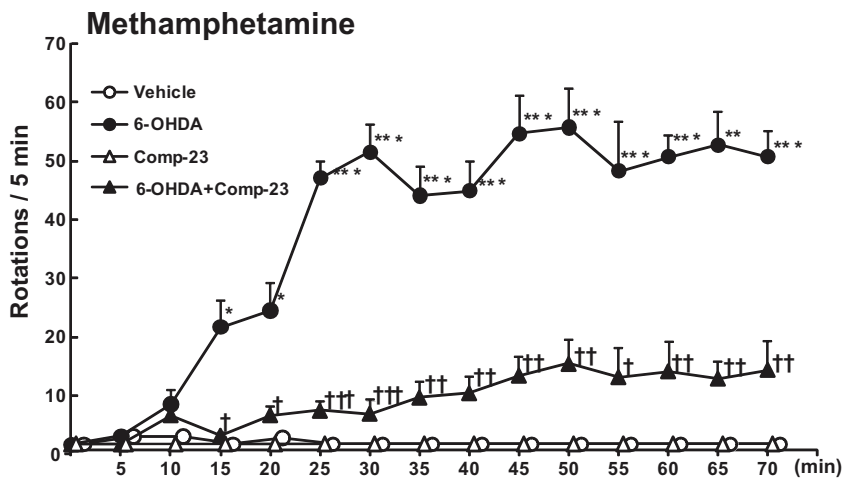

Figure 7 Changes in methamphetamine-induced rotational behaviour in 6-OHDA-injected rats that had been co-injected or not coinjected with DJ-1-binding compound-23. Rats were simultaneously injected with the vehicle (each $n=4$ ) or $32 \mathrm{nmol}$ of 6 -OHDA (each $n=$ 6) in the presence $(n=6)$ or absence $(n=4)$ of 4 nmol of DJ-1-binding compound-23 (comp-23) in a final volume of $4 \mu \mathrm{L}$ sterilized physiological saline containing $0.02 \%$ ascorbic acid and 1\% DMSO. Rotational behaviour was assessed at 7 days after 6-OHDA injection. The number of full body turns in the ipsilateral direction was counted for $70 \mathrm{~min}$ after the administration of methamphetamine $(2.5 \mathrm{mg} / \mathrm{kg}$, i.p.). Each value is the mean \pm SEM. Significance (Bonferroni/Dunn post hoc comparisons after ANOVA in A; Student's $t$-test in B): ${ }^{*} P<0.05$, ${ }^{* *} P<0.01,{ }^{* * *} P$ $<0.001$ vs. vehicle control rats. $+P<0.05,+\uparrow P<0.01,++\uparrow P<0.001$ versus $6-O H D A$-injected rats. 


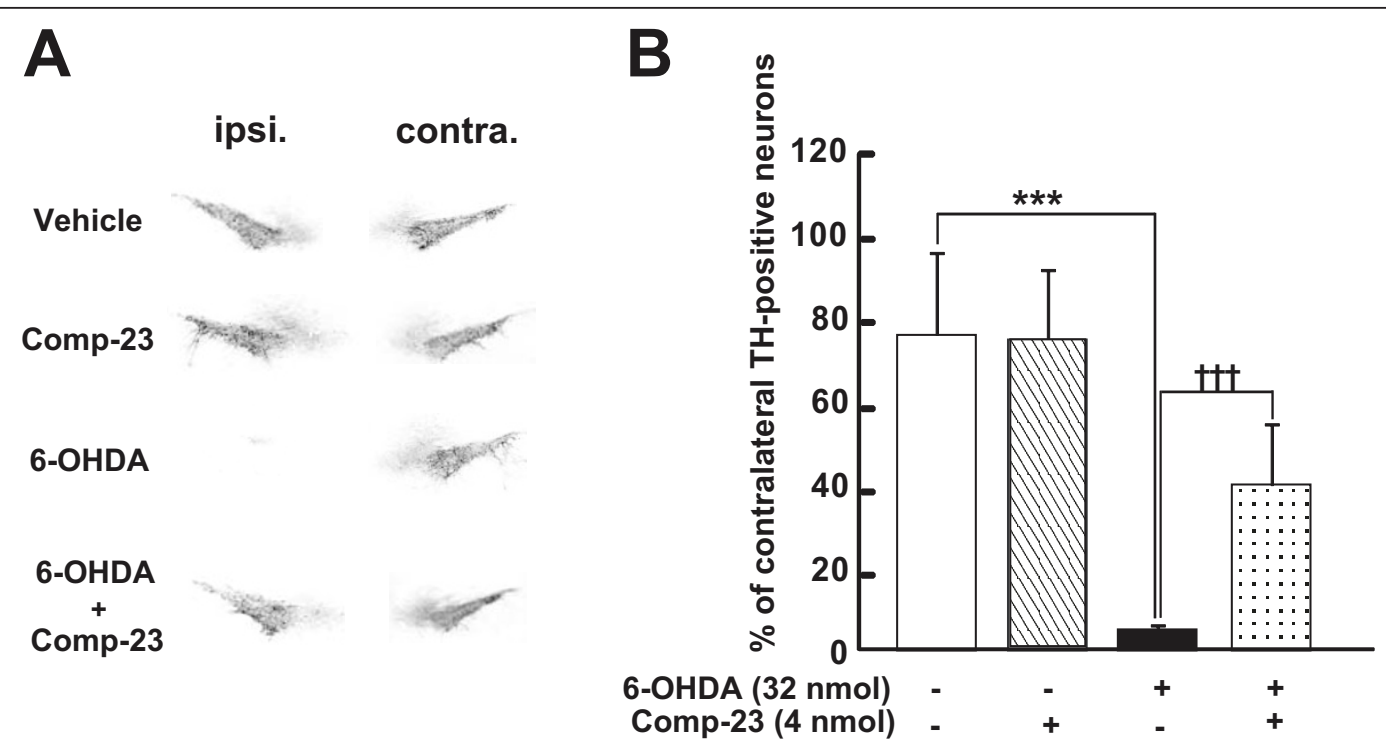

Figure 8 Semi-quantitative analysis of dopaminergic neurons in the substantia nigra. Co-administration of 6-OHDA and DJ-1-binding compound-23 (comp-23) was performed in rats injected with 6-OHDA into the left substantia nigra. After 10 days, treated rats were fixed and brain slices were prepared. (A) Midbrain slices were immunostained by anti-TH antibody. (B) $100 \%$ is the number of TH-immunopositive neurons in the contralateral substantia nigra (naive hemisphere). Each value is the mean \pm SEM of TH-immunopositive neurons in ipsilateral nigral sections from treated rats (each group, $n=4-6$ ). Significance (Bonferroni/Dunn post hoc comparisons after ANOVA): ***P 0.001 versus vehicle control rats. $+\uparrow+P<0.001$ vs. $6-\mathrm{OHDA}$-injected rats.

We have previously shown that chronic oral administration to C57BL/6 mice with rotenone (a selective inhibitor for mitochondrial complex I) at $30 \mathrm{mg} / \mathrm{kg}$ for $28-56$ days selectively induced nigrostriatal dopaminergic neurodegeneration and motor deficits, and increased the cytoplasmic accumulation of $\alpha$-synuclein in surviving dopaminergic neurons, similar to the early stage of PD neuropathological episodes [30,31]. To investigate whether peripheral administration of comp-23 protects motor function from damage caused by the chronic oral administration of rotenone $(30 \mathrm{mg} / \mathrm{kg}$ p.o. once a day for 56 days), we treated C57BL/6 mice with comp-23 (1 $\mathrm{mg} / \mathrm{kg}$ i.p. once a day for 56 days) $30 \mathrm{~min}$ before the oral administration of rotenone. To identify deficits in motor coordination, rotenone-treated mice were tested weekly on the accelerating rota-rod. Under this condition, vehicle-treated control mice usually remained on the rota-rod for over $200 \mathrm{sec}$ under stepwise acceleration. Rotenone-treated mice showed marked reduction in endurance time and in the percentage of mice remaining on the rota-rod (running survivors). In contrast, comp-23 (1 mg/kg i.p.) provided a significant functional recovery of the retention time on the rotarod (Figure 12). Thus, chronic peripheral administration of comp-23 improves rotenone-induced Parkinsonian motor dysfunction.

\section{Discussion}

In this study, we identified a new DJ-1-binding compound, compound-23 (comp-23), from the Zinc compound library, and we found that comp-23 prevented oxidative stress-induced cell death both in cultured cells and in PD and ischemia model rats and mice. Comp-23 prevented cell death even at a high concentration of $\mathrm{H}_{2} \mathrm{O}_{2}$, a condition in which DJ-1-binding compound B did not show protective activity against cell death, suggesting that activity of comp-23 is stronger than that of compound B at least in cultured cells. Structures of comp-23 and comp-B appear similar at a glance but are clearly different, especially in the position of an amino group and benzene ring. Since the X-ray co-crystal structure of DJ-1 with compound B has not yet been elucidated, an exact binding structure of compound B within DJ-1 is not known at present. Determination of the structure-activity relationships between DJ-1 and DJ-1-binding compounds will be necessary to establish DJ-1-binding compounds that are more effective than compounds B and 23. The Zinc compound library used in this study is freely available. If other libraries are used for screening of DJ-1-binding compounds, novel compounds might be obtained.

Although comp-23 lacks direct scavenging activity against $\mathrm{OH}$ (Figure 5), comp-23 protected $\mathrm{SH}-\mathrm{SY} 5 \mathrm{Y}$ 


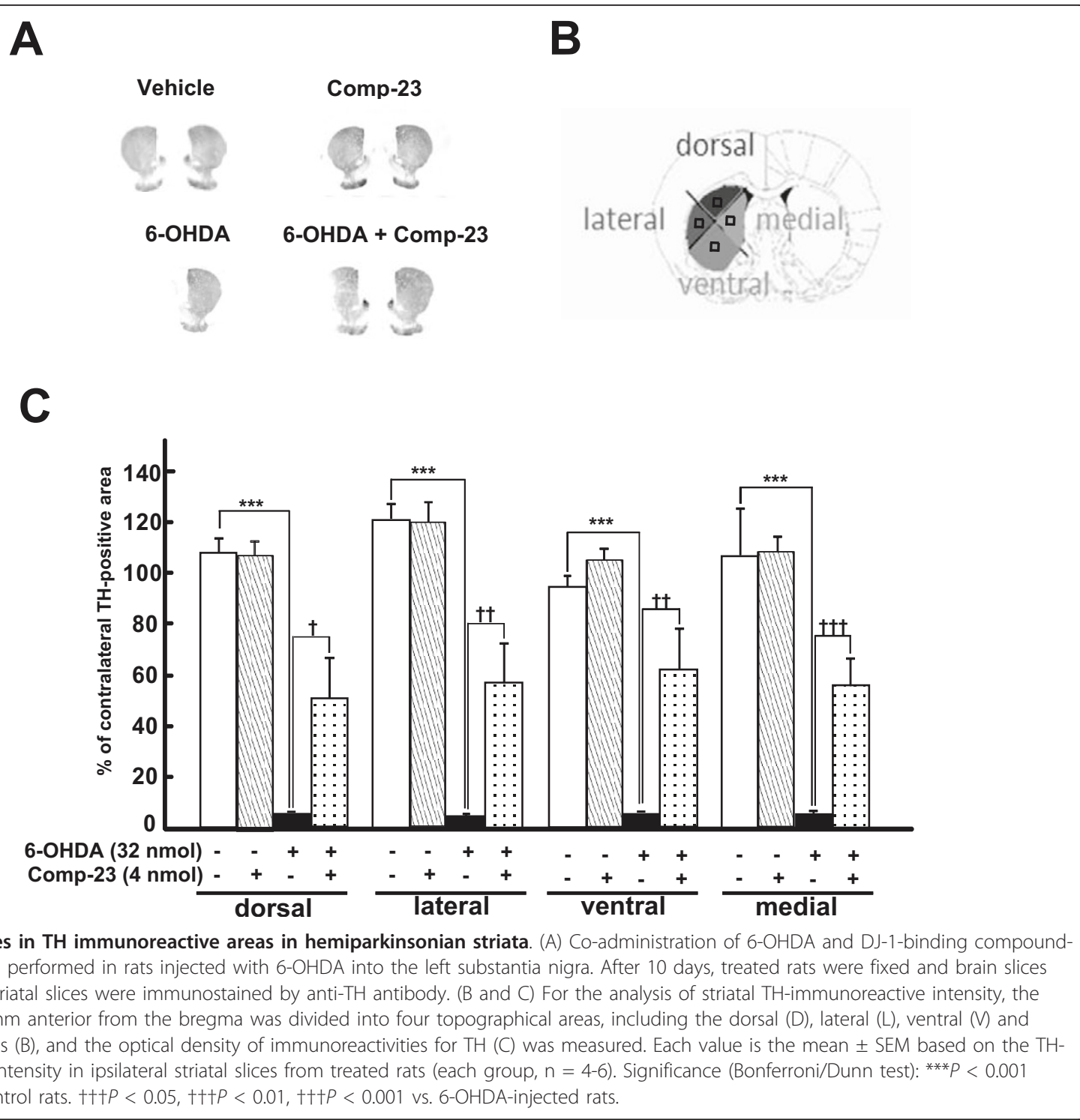

cells and primary rat neurons from oxidative stressinduced cell death (Figures 1, 2, and 3). Since comp-23 did not show a protective effect against oxidative stressinduced cell death in DJ-1-knockdown SH-SY5Y cells (Figure 4), comp-23 works in a DJ-1-dependent manner. Since a residual amount of DJ-1 was still expressed in DJ-1-knockdown SH-SY5Y cells, no protective activity of comp-23 in DJ-1-knockdown cells suggests that there is a threshold amount of DJ-1 for DJ-1-binding compounds to function in cells. Comp-23 prevented dopaminergic cell death both in the substantia nigra and striatum in 6-OHDA-administered PD model rats, resulting in suppression of locomotion defect of rats (Figures 7, 8, 9, 10, 11). Since a precursor of dopamine, inhibitors of dopamine degradation and dopamine releasers are used for PD therapy at present and since these drugs are used for symptomatic therapy, cell death progresses during treatment. In the present study, the intraperitoneal injection of comp-23 at before and after MCAO induced neuroprotection in a dose-dependent manner (Figure 11), and peripheral administration of comp-23 for 56 days prevented rotenone-induced Parkinsonian motor deficit (Figure 12). Based on these observations, we consider that comp-23 binds to endogenous DJ-1 protein after passing through the BBB and that this DJ-1-comp-23 complex shows the neuroprotective effect against ROSmediated dopaminergic neurodegeneration. Thus, there is a possibility that chronic peripheral administration of comp-23 delays the progression of motor dysfunction in $\mathrm{PD}$ and/or brain stroke.

Comp-23 is not a simple anti-oxidant (Figure 5) and prevented excess oxidation of DJ-1 in cells that had 


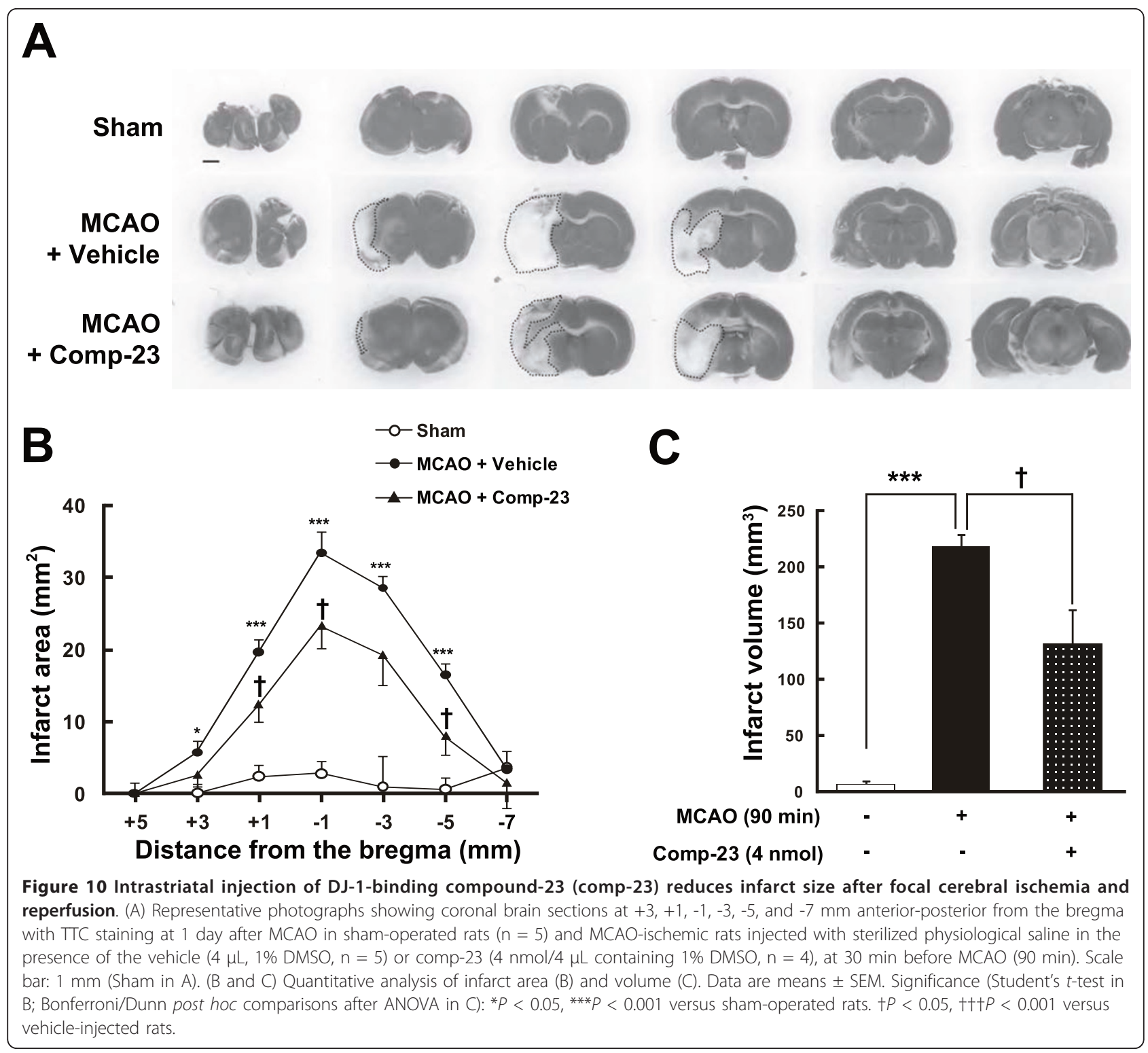

been treated with various amounts of $\mathrm{H}_{2} \mathrm{O}_{2}$ (Figure 6A). Since excess oxidation of DJ-1 renders DJ-1 inactive, it is thought that comp-23 activates DJ-1 or maintains active forms of DJ-1, thereby affecting downstream targets of DJ-1. DJ-1, for instance, activates Nrf2, a master transcription factor of redox-related genes, by sequestering Keap1, a negative factor of Nrf2 [32], and also activates the PI3 kinase/AKT pathway by inhibiting PTEN, a negative effecter of the PI3 kinase/AKT pathway, through direct binding with PTEN [22,33,34]. Screening strategy is to identify compounds that bind to weakly oxidized DJ-1 with an $\mathrm{SO}_{2} \mathrm{H}$ form of $\mathrm{C} 106$ using a model of such an oxidized DJ-1. Since reduced DJ-1 and oxidized DJ-1 are unable to be separately purified due to technical problem at present, we are not able to determine which form of DJ-1 is bound by comp-23. In vitro binding assays showed that comp-23 bound to recombinant DJ-1 that contains equal molar ratio of reduced and oxidized DJ-1 (Figure 1C), suggesting that comp-23 binds to both reduced DJ-1 and oxidized DJ-1. Furthermore, we examined dimer formation of DJ-1 in the presence and absent of comp-23. The results showed that comp-23 did not affect dimer formation of DJ-1 (Figure 6B). Since DJ-1 works as dimer, it is thought that dimer DJ-1 complexed with comp-23 shows protective activity against oxidative stress-induced neurodegeneration.

Reactive oxygen species are massively produced in the brain after cerebral ischemia and reperfusion. The antioxidant edaravone (3-methyl-1-phenyl-2-pyrazolin-5- 


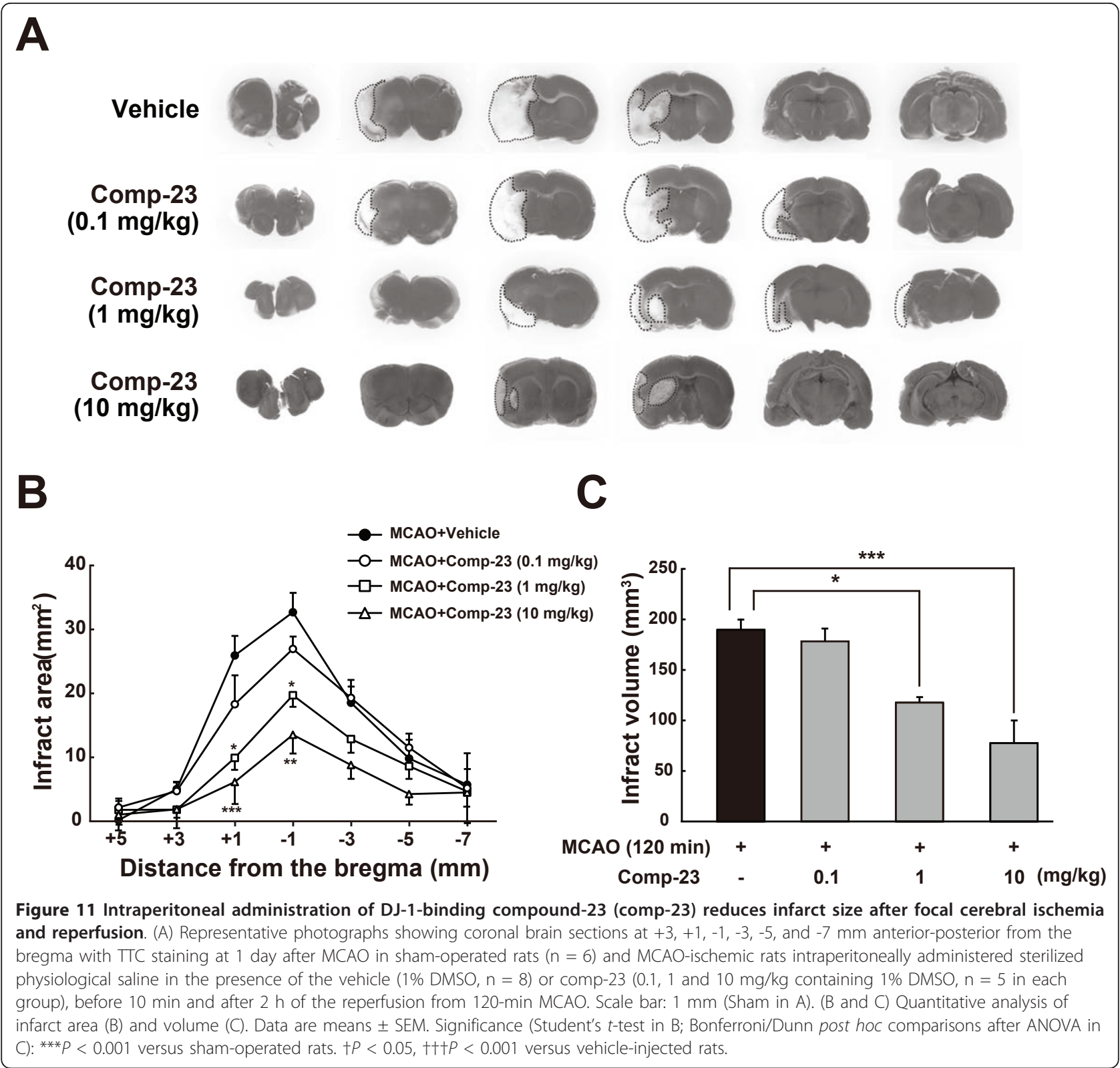

one) has been used as a brain protectant for stroke therapy and is effective within 24 hours after onset of stroke. It has been reported that DJ-1 immunoreactivity in human brain astrocytes is dependent on infarct presence and infarct age [35], that DJ-1 is expressed in motor neurons after transient spinal cord ischemia in rabbits [36] and that loss of DJ-1 increases the sensitivity to excitotoxicity and ischemia [27]. We and other group have reported that injection of DJ-1 or infection of DJ1 -containing virus reduced infarct size in cerebral ischemia in rats $[21,22]$. Furthermore, we have shown that administration of DJ-1-binding compound B also reduced infarct size of cerebral ischemia in rats [24]. It is therefore thought that, like a PD model, comp-23 maintains activated forms of DJ-1 to activate Nrf2 and the AKT pathway, leading to reduction of ROS and to promotion of cell growth in ischemia model rats.

\section{Conclusions}

In this study, we identified a new DJ-1-binding compound, comp-23. Comp-23 prevented dopaminergic cell death in the substantia nigra and restored movement abnormality in 6-hydroxyldopamine-injected PD model rats and in rotenone-treated PD model mice. Comp-23 also reduced infarct size of cerebral ischemia in rats that had been induced by middle cerebral artery occlusion. Protective activity of comp- 23 seemed to be stronger than that that of previously identified compound $\mathrm{B}$ at 
A

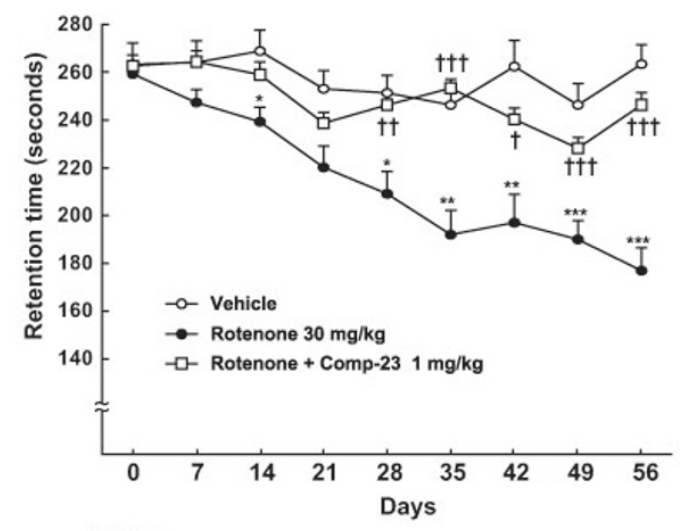

B

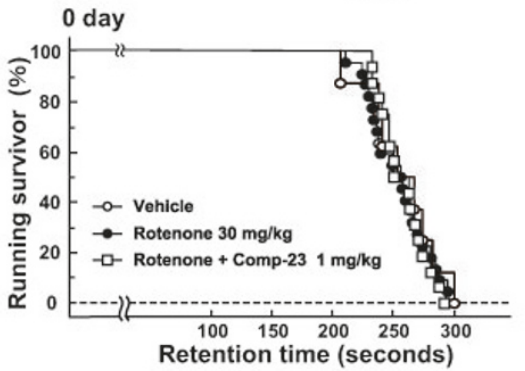

C

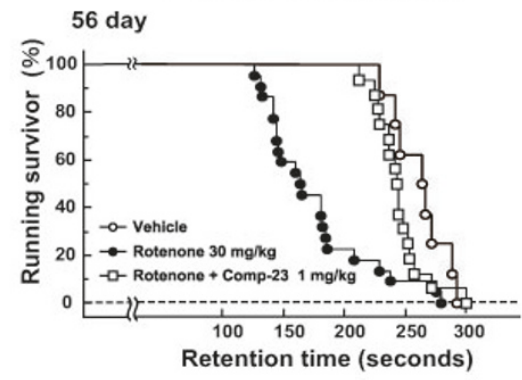

Figure 12 Suppression of rotenone-induced behavioral dysfunction by DJ-1-binding compound-23. Rotenone (suspended in $0.5 \%$ CMC) was orally administered to C57BL/6 mice at a dose of $30 \mathrm{mg} / \mathrm{kg}$ per day for 56 days. In addition, we injected mice with vehicle (closed circles; $1 \%$ DMSO, $\mathrm{n}=22$ ) or comp-23 (open squares; $1 \mathrm{mg} / \mathrm{kg}$ i.p., $\mathrm{n}=16$ ) once a day for 56 days, 30 min before the oral administration of rotenone. The vehicle control mice (open circles; $n=8$ ) were received 0.5\% CMC (p.o.) and 1\% DMSO (i.p.) for 56 days. (A) The rota-rod test was performed every week. The speed of the rotating rod was accelerated in a stepwise manner (2 r.p.m, steps at intervals of 30 sec). Mice that had received oral rotenone showed significant motor dysfunction. This rotenone-induced dysfunction was significantly restored by administration of comp-23. Significance: ${ }^{*} P<0.05$, ${ }^{*} P<0.01$, ${ }^{* *} P<0.001$ vs. vehicle. $t p<0.05,+\dagger p<0.01$, $+\uparrow t p<0.001$ vs rotenone alone. (B and C) Timedependent changes in the percentage (\%) of mice remaining on the rotating rod at 0 (B) and 56 days (C). Mice that had received oral rotenone showed significantly greater motor dysfunction than those that had received vehicle at 56 days ( $p=0.0016$ by the log-rank test, $C)$. Rotenoneinduced motor dysfunction was significantly restored by administration of comp-23 ( $p=0.0019$ by the log-rank test, C).

least in cultured cells. Com-23 will become a lead compound for PD and stroke.

\section{Methods}

\section{Materials}

N-[4-(8-methyl(4-hydroimidazo[1,2-a]pyridin-2-yl))phenyl](3,4,5-trimethoxyphenyl)carboxamide, which is DJ-1binding compound-23 (comp-23), was synthesized and obtained by Enamine Ltd. (Kiev, Ukraine). 6-Hydroxydopamine (6-OHDA) and DCFH-DA were purchased from Sigma (St. Louis, MO, USA) and from Invitrogen (Carlsbad, CA, USA), respectively. Mouse anti-tyrosine hydroxylase $(\mathrm{TH})$, chicken anti-TH and anti-NeuN antibodies were purchased from Sigma, Chemicon (Temecula, CA, USA) and Chemicon, respectively. The ABC Elite kit from Vector Laboratories (Burlingame, CA, USA) was used. Methamphetamine was obtained from Dainippon Sumitomo Pharmaceutical Co., Ltd. (Osaka, Japan).

\section{Cell culture}

Human SH-SY5Y and its DJ-1-knockdown cells were cultured in Dulbecco's modified Eagle's medium (DMEM) 
with $10 \%$ calf serum. Establishment of DJ-1-knockdown SH-SY5Y cells was described previously [17].

\section{Screening of DJ-1-binding compounds}

Information on the X-ray crystal structures of reduced DJ-1 and oxidized DJ-1 at $\mathrm{C} 106$ as an $\mathrm{SO}_{2} \mathrm{H}$ form was obtained from a web site (http://www.rcsb.org/pdb/). To obtain the structure of DJ-1 containing $\mathrm{H}_{2} \mathrm{O}$, the X-ray crystal structure of DJ-1 was modified using BioMedCAChe software (Fijitsu, Tokyo, Japan). Compounds were screened by targeting C106 of this structure on FastDock software (Fijitsu) in BioServer hardware (Fujitsu) according to the manufacturer's protocol. Briefly, the BioServer hardware used is PC clusters with 40 core of CPU of Xeon5355 (Fujitsu), OS of Red Hat 3.4.5-2 (Linux version 2.6.9-34) and 1.0 TB Hard Disk. The other conditions were exactly the same as those described previously [23].

\section{Cell viability assay}

Cells were cultured in a 96-well plate and treated with various amounts of hydrogen peroxide or 6-OHDA. Cell viability was then measured by a 3-(4,5-dimethylthiazol2-yl)-2,5-diphenyltetrazolium bromide (MTT) assay using a cell counting kit -8 (DOJINDO, Osaka, Japan).

\section{Binding of compound-23 to DJ-1 by a quartz crystal microbalance}

Fixation of compounds on a sensor chip of QCM (Affinix Q, Initium, Tokyo, Japan) was carried out as follows. The sensor chip was washed with a solution containing $\mathrm{H}_{2} \mathrm{O}_{2}$ and sulfonic acid (molar ratio = 1:3), and then it was incubated with $4 \mu \mathrm{L}$ of $1 \mu \mathrm{M}$ compound dissolved in chloroform until the solution had evaporated. To the sensor chips fixed with compounds in Affinix Q, $8 \mu \mathrm{L}$ of $1 \mu \mathrm{g} / \mu \mathrm{L}$ DJ-1 was applied, and their frequency was measured according to the manufacturer's protocol.

\section{Primary neuronal culture of the ventral mesencephalon}

Cultures of the rat mesencephalon were established according to methods described previously [37]. The ventral two-thirds region of the mesencephalon was dissected from rat embryos on the 17-19th days of gestation. The dissected regions included dopaminergic neurons from the substantia nigra and the ventral tegmental area but not noradrenergic neurons from the locus ceruleus. Neurons were dissociated mechanically and plated out onto $0.1 \%$ polyethyleneimine-coated 24 well plates at a density of $2.5 \times 10^{6}$ cells/well. The culture medium consisted of DMEM containing 10\% fetal calf serum for 2 days and DMEM containing 2\% B-27 supplement (Invitrogen) and $2 \mu \mathrm{g} / \mathrm{mL}$ aphidicolin (Sigma) without fetal calf serum from the third day onwards. The animals were treated in accordance with guidelines published in the NIH Guide for the Care and Use of Laboratory Animals. After fixation, cultured cells were incubated with chicken anti-TH (diluted at 1:200) and anti-NeuN (1:200) antibodies for 24 hours at $25^{\circ} \mathrm{C}$. The cells were also stained with 4',6-diamidino-2-phenylindole (DAPI). The cells were then reacted with a rhodamine-conjugated anti-rabbit IgG or fluorescein isothiocyanate-conjugated anti-mouse IgG and observed under an All-in-on microscope (Biorevo BZ-9000, Keyence).

To examine the effects of DJ-1-binding compounds on oxidative stress-induced cell death, the cells were cultured in the presence or absence of $1 \mu \mathrm{M}$ of each compounds for 20 hours and then treated with $200 \mu \mathrm{M}$ $\mathrm{H}_{2} \mathrm{O}_{2}$ for 3 hours. Cell viabilities were then examined by an MTT assay.

\section{Detection of production of ROS}

$8 \times 10^{5} \mathrm{SH}-\mathrm{SY} 5 Y$ cells in a 96-well plate were pretreated with $1 \mu \mathrm{M}$ of comp-23 for 20 hours and then treated with $40 \mu \mathrm{M} 6$-OHDA for $10 \mathrm{~min}$ after the addition of $10 \mu \mathrm{M}$ DCFA-DA (Invitrogen) for $15 \mathrm{~min}$. The amounts of ROS in cells were measured using a fluorescence spectrophotometer at extension of $485 \mathrm{~nm}$ and emission of $530 \mathrm{~nm}$.

\section{Isoelectric focusing}

SH-SY5Y cells were incubated with $1 \mu \mathrm{M}$ compound-23 or compound- $\mathrm{B}$ for 24 hours and then treated with various amounts of $\mathrm{H}_{2} \mathrm{O}_{2}$ for $10 \mathrm{~min}$. Proteins extracted from the cells were separated in the $\mathrm{pH} 5-8$ range of isoelectric focusing phoresis gel, transferred to nitrocellulose membranes, and blotted with an anti-DJ-1 polyclonal antibody as described previously [10].

\section{Dimer formation}

SH-SY5Y cells in 6-well plates were incubated with 1 $\mu \mathrm{M}$ compound-23 or compound-B for 20 hours and then treated with various amounts of $\mathrm{H}_{2} \mathrm{O}_{2}$ for 3 hours. Cells were then treated with $0.5 \mathrm{mM}$ DSS or DMSO for $30 \mathrm{~min}$, and proteins extracted from cells were analyzed by Western blotting with an anti-DJ-1 antibody.

\section{ESR spectrometry}

The hydroxyl radical $(\cdot \mathrm{OH})$ was monitored by ESR spectrometry with 5,5-dimethyl-1-pyrroline- $N$-oxide (DMPO; Labotec Ltd., Tokyo, Japan), a spin trapper. In a final volume of $200 \mu \mathrm{L}$ of $100 \mathrm{mM}$ phosphate buffer (PB), comp-23 (1-100 $\mu \mathrm{M})$ or thiourea $(500 \mathrm{mM})$ was added to the reaction mixture containing diethylene-triamine pentaacetic acid $(25 \mu \mathrm{M}), \mathrm{FeSO}_{4}(25 \mathrm{mM}), \mathrm{H}_{2} \mathrm{O}_{2}(100$ $\mu \mathrm{M})$, and DMPO (112.5 $\mathrm{mM})$. These drugs and reagents were solubilized in Milli Q water. The reaction mixture was transferred to a flat quartz cuvette and placed in 
the cavity of an X-band JEOL RFR-30bRadical Analyzer system (JEOL Ltd., Tokyo, Japan). The $\mathrm{OH}$, which was generated by Fenton's reaction between $\mathrm{Fe}^{2+}$ and $\mathrm{H}_{2} \mathrm{O}_{2}$, was trapped by DMPO, and a stable adduct DMPO-OH was measured exactly $1 \mathrm{~min}$ after the addition of DMPO. The $\mathrm{Mn}^{2+}$-derived split signal was used as the internal standard. Typical instrumental stettings were as follows: incident-microwave of $4 \mathrm{mV}$, modulation-amplitude of $0.1 \mathrm{mT}$, time-constant of $0.10 \mathrm{~s}$, and sweep rate of $5 \mathrm{mT} / \mathrm{min}$.

\section{Hemiparkinsonian rats}

Male Wistar rats (SLC, Shizuoka, Japan) weighing approximately $250 \mathrm{~g}$ were used. Rats were acclimated to and maintained at $23^{\circ} \mathrm{C}$ under a 12-hour light and dark cycle (light on 08:00-20:00 hours). All animal experiments were carried out in accordance with the National Institutes of Health Guide for the Care and Use of Laboratory Animals, and the protocols were approved by the Committee for Animal Research at Kyoto Pharmaceutical University. For stereotaxic microinjection, rats were anesthetized (sodium pentobarbital, $50 \mathrm{mg} / \mathrm{kg}$, i.p.) and immobilized in a Kopf stereotaxic frame. Subsequently, rats were simultaneously injected with 6-OHDA $(32 \mathrm{nmol} / 4 \mu \mathrm{L})$ in the presence or absence of comp-23 $(4 \mathrm{nmol} / 4 \mu \mathrm{L})$, in a final volume of $4 \mu \mathrm{L}$ of physiological saline containing $0.02 \%$ ascorbic acid (as a 6-OHDA stabilizer) and 1\% dimethyl sulfoxide (DMSO, as a solvent for comp-23). As a vehicle control, sterilized physiological saline containing $0.02 \%$ ascorbic acid and $1 \%$ DMSO was injected without 6-OHDA. The intranigral injection coordinates $4.8 \mathrm{~mm}$ anterior-posterior, $1.8 \mathrm{~mm}$ left lateral, and $7.8 \mathrm{~mm}$ ventral from the bregma were taken from a rat brain atlas. Injection was performed by a motor-driven 10- $\mu$ l Hamilton syringe using a 26gauge needle. The infusion rate was $1 \mu \mathrm{L} / \mathrm{min}$, and the injection needle was kept in place for a further 5 min after injection. At the end of the experiments, all rats were sacrificed for immunohistochemical assessments.

\section{Assay of rotational behavior}

We used methamphetamine as a dopamine releaser [38]. Drug-induced rotational asymmetry was assessed in rotometer bowls as described previously $[20,23,39]$. Briefly, the number of full body turn rotations in the ipsilateral direction was counted after the administration of methamphetamine $(2.5 \mathrm{mg} / \mathrm{kg}$, i.p., for $70 \mathrm{~min}$ ).

\section{Tissue preparation and immunohistochemistry}

After assay of rotational behaviour, treated rats were perfused through the aorta with $150 \mathrm{~mL}$ of $10 \mathrm{mM}$
PBS, followed by $300 \mathrm{~mL}$ of a cold fixative consisting of $4 \%$ paraformaldehyde in $100 \mathrm{mM}$ phosphate buffer $(\mathrm{PB})$ under deep anesthesia with pentobarbital (100 $\mathrm{mg} / \mathrm{kg}$, i.p.). After perfusion, the brain was quickly removed and postfixed for 2 days with paraformaldehyde in $100 \mathrm{mM} \mathrm{PB}$ and then transferred to $15 \%$ sucrose solution in $100 \mathrm{mM} \mathrm{PB}$ containing $0.1 \%$ sodium azide at $4{ }^{\circ} \mathrm{C}$. The brain was cut into $20-\mu \mathrm{m}$ thick slices using a cryostat and collected in $100 \mathrm{mM}$ PBS containing $0.3 \%$ Triton X-100 (PBS-T). Brain slices were incubated with a mouse anti-TH antibody $\left(1: 10,000\right.$, dilution) for 3 days at $4^{\circ} \mathrm{C}$. After several washes, sections were incubated with biotinylated antimouse IgG antibody (1:2,000), as appropriate, for 2 hours at room temperature. The sections were then incubated with avidin peroxidase (1:4,000; ABC Elite Kit; Vector Laboratories, Burlingame, CA, USA) for 1 hour at room temperature. All of the sections were washed several times with PBS-T between each incubation, and labeling was then revealed by 3,3'-diaminobenzidine $(\mathrm{DAB})$ with nickel ammonium, which yielded a dark blue colour $[20,23]$.

\section{Measurement of immunoreactive neurons and areas}

The number of $\mathrm{TH}$-immunopositive neurons in the substantia nigra and the optical density of TH-immunoreactive areas in the striatum were measured by a computerized image analysis system (WinRoof; Mitani, Tokyo, Japan) with a CCD camera (ProgRes 3008, Carl Zeiss, Jena, Germany) as described previously [20,23]. The number of TH-immunopositive neurons in the substantia nigra was counted bilaterally on six adjacent sections between 4.6 and $4.9 \mathrm{~mm}$ posterior from the bregma. For each animal, neuronal survival in the substantia nigra was then expressed as the percentage of $\mathrm{TH}$-immunopositive neurons on the lesioned side, with respect to the contralateral, intact side; this approach was chosen to avoid methodological biases because of interindividual differences and is widely used to assess the extent of a 6-OHDA-induced lesion in the substantia nigra [40-42].

For the analysis of striatal TH-immunoreactive intensity, the striatum was divided into anatomo-functional quadrants encompassing the dorsal (D), lateral (L), ventral $(\mathrm{V})$, and medial $(\mathrm{M})$ regions $[41,43]$ and the optical density was measured within a fixed box $(0.5 \times 0.5 \mathrm{~mm})$ positioned approximately in the middle of these quadrantal parts. Immunoreactive intensity was expressed as percentage of the intensity recorded from the same area on the contralateral side $[40,43,44]$. Subsequently, the average of relative intensities in each quadrant was estimated from striatal slices (at $0.60 \mathrm{~mm}$ anterior from the bregma) and then statistical values were evaluated from treated rats. 


\section{In vivo model of rat focal cerebral ischemia}

Male Wistar rats weighing 260-300 g were used. Focal cerebral ischemia was induced by the intraluminal introduction of a nylon thread as described previously [21]. Briefly, animals were anesthetized with $4 \%$ halothane (Takeda Pharmaceutical, Osaka, Japan) and maintained on $1.5 \%$ halothane using a facemask. After a midline neck incision had been made, $20 \mathrm{~mm}$ of 4-0 nylon thread with its tip rounded by heating and coated with silicone (Xantopren M; Heraeus Kulzer, Hanau, Germany) was inserted into the left internal carotid artery (ICA) as far as the proximal end using a globular stopper. The origin of the middle cerebral artery (MCA) was then occluded by a silicone-coated embolus. Anesthesia was discontinued, and the development of right hemiparesis with upper limb dominance was used as the criterion for ischemic insult. After 90 or $120 \mathrm{~min}$ of MCA occlusion (MCAO), the embolus was withdrawn to allow reperfusion of the ischemic region via the anterior and posterior communicating arteries. Body temperature was maintained at $37-37.5^{\circ} \mathrm{C}$ with a heating pad and lamp during surgery. In the sham operation, a midline neck incision was made to expose the arteries, but the nylon thread was not inserted into the carotid artery.

\section{Intrastriatal drug administration to ischemic rats}

Ninety-min-MCAO-ischemic rats (SLC, Shizuoka) were used. Under deep anesthesia (sodium pentobarbital, 50 $\mathrm{mg} / \mathrm{kg}$, i.p.), rats received a microinjection of comp-23 $(4 \mathrm{nmol} / 4 \mu \mathrm{L})$ in the left striatum (coordinates: $1 \mathrm{~mm}$ anterior, $4 \mathrm{~mm}$ left lateral, and $5 \mathrm{~mm}$ ventral from the bregma). Sterilized physiological saline containing $1 \%$ DMSO was used as the vehicle control in a final volume of $4 \mu \mathrm{L}$. After $30 \mathrm{~min}$, left MCAO for $90 \mathrm{~min}$ and reperfusion were performed.

\section{Intraperitoneal drug administration to ischemic rats}

One hundred twenty-min-MCAO-ischemic rats were used. Animals were intraperitoneally administered with comp-23 $(0.1,1$ and $10 \mathrm{mg} / \mathrm{kg})$, before $10 \mathrm{~min}$ and after 2 hours of the reperfusion from MCAO. Sterilized physiological saline containing 1\% DMSO was used as a vehicle control.

\section{Measurement of infarct volume in rat ischemic brain}

At 24 hours after MCAO, brains were removed and cut into 2 -mm-thick coronal sections. These sections were immersed in 2\% solution of 2,3,5-triphenyltetrazolium chloride (TTC; Wako Pure Chemical Industries, Osaka, Japan) in saline at $37^{\circ} \mathrm{C}$ for $20 \mathrm{~min}$ and then fixed in $4 \%$ paraformaldehyde in $100 \mathrm{mM}$ phosphate buffer $(\mathrm{PB})$ at $4^{\circ} \mathrm{C}$, and infarct areas and volumes were quantified.
Rotenone-treated PD model mice and rota-rod test

Rotenone (Sigma, St. Louis, MO, USA) was administered orally once daily at a dose of $30 \mathrm{mg} / \mathrm{kg}$ for 56 days, as described previously [30,31]. Rotenone was suspended in $0.5 \%$ carboxymethyl cellulose sodium salt (CMC, Nacalai Tesque, Kyoto, Japan) and administered orally once daily at a volume of $5 \mathrm{~mL} / \mathrm{kg}$ body weight. 0.5\% CMC was administered orally as vehicle to control mice.

Behaviour of each mouse was assessed by the rota-rod test, as also described previously [30,31]. The rota-rod treadmill (accelerating model 7750, Ugo Basile, Varese, Italy) consists of a plastic rod, $6 \mathrm{~cm}$ in diameter and 36 $\mathrm{cm}$ long, with a non-slippery surface $20 \mathrm{~cm}$ above the base (trip plate). This rod is divided into four equal sections by five discs $(25 \mathrm{~cm}$ in diameter), which enables four mice to walk on the rod at the same time. In the present study, the accelerating rotor mode was used (10-grade speeds from 2 to 20 r.p.m. for $5 \mathrm{~min}$ ). The performance time was recorded while mice were running on the rod.

\section{Statistical evaluation}

All data are presented as means \pm standard error of the mean (SEM). The significance of differences was determined by one-way analysis of variance (ANOVA). Further statistical analysis for post hoc comparisons was performed using the Bonferroni/Dunn tests (StatView; Abacus Concepts, Berkeley, CA, USA). On the other hand, the significance of difference in rotation numbers/ $5 \mathrm{~min}$ and that of difference in areas of survival neurons in 6-OHDA-injected rats and $\mathrm{MCAO}$-ischemic rats were determined by Student's $t$-test for single comparisons. Endurance performance (percentage of mice remaining on the rota-rod) was calculated by the Kaplan-Meier method. The statistical significance of differences was analyzed by the log-rank (Mantel-Cox) test.

\section{Abbreviations}

The abbreviations used are PD: Parkinson's disease; comp-23: compound 23; 6-OHDA: 6-hydroxydopamine; MCA: middle cerebral artery; MCAO: MCA occlusion; ROS: reactive oxygen species; TH: tyrosine hydroxylase; MTT: 3(4,5-dimethylthiazol-2-yl)-2,5-diphenyltetrazolium bromide.

\section{Acknowledgements and Funding}

We thank Kiyomi Takaya for her technical assistance. This work was supported by grants-in-aid from the Ministry of Education, Science, Culture and Sports and by the Program for Promotion of Fundamental Studies in Health Science of the National Institute of Biomedical Innovation (NIBIO) in Japan.

\footnotetext{
Author details

'Department of Neurobiology, Kyoto Pharmaceutical University, Kyoto 6078414, Japan. ${ }^{2}$ Graduate School of Agriculture, Hokkaido University, Sapporo, Japan. ${ }^{3}$ Department of Analytical and Bioinorganic Chemistry, Kyoto Pharmaceutical University, Kyoto 607-8414, Japan. ${ }^{4}$ Graduate School of Pharmaceutical Sciences, Hokkaido University, Sapporo, Japan.
} 


\section{Authors' contributions}

HA and SMMI-A conceptualized the study; YK, SW, MT, KT, TK, KT-N and HY carried out experiments; HM conducted the analyses and YK and HA wrote the manuscript. All authors read and approved the final manuscript.

\section{Competing interests}

The authors declare that they have no competing interests.

Received: 4 February 2011 Accepted: 8 July 2011 Published: 8 July 2011

\section{References}

1. Nagakubo D, Taira T, Kitaura H, Ikeda M, Tamai K, Iguchi-Ariga SMM Ariga H: DJ-1, a novel oncogene which transforms mouse NIH3T3 cells in cooperation with ras. Biochem Biophys Res Commum 1997, 231:509-513.

2. Bonifati V, Rizzu P, van Baren MJ, Schaap O, Breedveld GJ, Krrieger E, Dekker MC, Squitieri F, Ibanez P, Joosse M, van Dongen JW, Vanacore N, van Swieten JC, Brice A, Meco G, van Duijn CM, Oostra BA, Heutink P: Mutations in the $D J-1$ gene associated with autosomal recessive earlyonset Parkinsonism. Science 2003, 299:256-259.

3. Takahashi K, Taira T, Niki T, Seino C, Iguchi-Ariga SMM, Ariga H: DJ-1 positively regulates the androgen receptor by impairing the binding of PIASx alpha to the receptor. J Biol Chem 2001, 276:37556-37563.

4. Niki T, Takahashi-Niki K, Taira T, Iguchi-Ariga SMM, Ariga H: DJBP: A novel DJ-1-binding protein, negatively regulates the androgen receptor by recruiting histone deacetylase complex, and DJ-1 antagonizes this inhibition by abrogation of this complex. Mol Cancer Res 2003, 1:247-261.

5. Shinbo Y, Taira T, Niki T, Iguchi-Ariga SMM, Ariga H: DJ-1 restores p53 transcription activity inhibited by Topors/p53BP3. Int J Oncol 2005, 26:641-648.

6. Zhong N, Kim CY, Rizzu P, Geula C, Porter DR, Pothos EN, Squitieri F, Heutink $P, X u$ J: DJ-1 transcriptionally up-regulates the human tyrosine hydroxylase by inhibiting the sumoylation of pyrimidine tract-binding protein-associated splicing factor. J Biol Chem 2006, 281:20940-20948.

7. Clements CM, MCNally RS, Conti BJ, Mak TW, Ting JP: DJ-1, a cancer- and Parkinson's disease-associated protein, stabilizes the antioxidant transcriptional master regulator Nrf2. Proc Natl Acad Sci USA 2006, 103:15091-15096.

8. Tillman JE, Yuan J, Gu G, Fazli L, Ghosh R, Flynt AS, Gleave M, Rennie PS, Kasper S: DJ-1 binds androgen receptor directly and mediates its activity in hormonally treated prostate cancer cells. Cancer Res 2007, 67:4630-4637.

9. Ishikawa S, Taira T, Takahashi-Niki K, Niki T, Ariga H, Iguchi-Ariga SMM: Human DJ-1-specific transcriptional activation of tyrosine hydroxylase gene. J Biol Chem 2010, 285:39718-39731.

10. Taira T, Saito Y, Niki T, Iguchi-Ariga SMM, Takahashi K, Ariga H: DJ-1 has a role in antioxidative stress to prevent cell death. EMBO Rep 2004, 5:213-218.

11. Yokota T, Sugawara K, Ito K, Takahashi R, Ariga H, Mizusawa H: Down regulation of DJ-1 enhances cell death by oxidative stress, ER stress, and proteasome inhibition. Biochem Biophys Res Commun 2003, 312:1342-1348.

12. Canet-Aviles RM, Wilson MA, Miller DW, Ahmad R, McLendon C Bandyopadhyay S, Baptista MJ, Ringe D, Petsko GA, Cookson MR: The Parkinson's disease protein DJ-1 is neuroprotective due to cysteinesulfinic acid-driven mitochondrial localization. Proc Natl Acad Sci USA 2004, 101:9103-9108.

13. Martinat C, Shendelman S, Jonason A, Leete T, Beal MF, Yang L, Floss T, Abeliovich A: Sensitivity to oxidative stress in DJ-1-deficient dopamine neurons: An ES derived cell model of primary Parkinsonism. PLOS Biol 2004, 2:e327.

14. Shendelman S, Jonason A, Martinat C, Leete T, Abeliovich A: DJ-1 is a redox-dependent molecular chaperone that inhibits alpha-synuclein aggregate formation. PLOS Biol 2004, 2:e362.

15. Takahashi-Niki K, Niki T, Taira T, Iguchi-Ariga SMM, Ariga H: Reduced antioxidative stress activities of DJ-1 mutants found in Parkinson's disease patients. Biochem Biophys Res Commun 2004, 320:389-397.

16. Zhou W, Zhu M, Wilson MA, Petsko GA, Fink AL: The oxidation state of DJ1 regulates its chaperone activity toward a-synuclein. J Mol Biol 2006, 356:1036-1048.
17. Ishikawa S, Taira T, Niki T, Takahashi-Niki K, Maita C, Maita H, Ariga H, IguchiAriga SMM: Oxidative status of DJ-1-dependent activation of dopamine synthesis through interaction of tyrosine hydroxylase and 4-dihydroxy-Lphenylalanine (L-DOPA) decarboxylase with DJ-1. J Biol Chem 2009, 284:28832-28844

18. Bandopadhyay R, Kingsbury AE, Cookson MR, Reid AR, Evans IM, Hope AD, Pittman AM, Lashley T, Canet-Aviles R, Miller DW, McLendon C, Strand C, Leonard AJ, Abou-Sleiman PM, Healy DG, Ariga H, Wood NW, de Silva R, Revesz T, Hardy JA, Lees AJ: The expression of DJ-1 (PARK7) in normal human CNS and idiopathic Parkinson's disease. Brain 2004, 127:420-430.

19. Choi J, Sullards MC, Olzmann JA, Rees HD, Weintraub ST, Bostwick DE, Gearing M, Levey Al, Chin LS, Li L: Oxidative damage of DJ-1 is linked to sporadic Parkinson and Alzheimer diseases. J Biol Chem 2006, 281:10816-10824.

20. Inden M, Taira T, Kitamura Y, Yanagida T, Tsuchiya D, Takata K, Yanagisawa D, Nishimura K, Taniguchi T, Kiso Y, Yoshimoto K, Agatsuma T, Koide-Yoshida S, Iguchi-Ariga SMM, Shimohama S, Ariga H: PARK7 DJ-1 protects against degeneration of nigral dopaminergic neurons in Parkinson's disease rat model. Neurobiol Dis 2006, 24:144-158.

21. Yanagisawa D, Kitamura Y, Inden M, Takata K, Taniguchi T, Morikawa S, Morita M, Inubushi T, Tooyama I, Taira T, Iguchi-Ariga SMM, Akaike A, Ariga H: DJ-1 protects against neurodegeneration caused by focal cerebral ischemia and reperfusion in rats. J Cereb Blood Flow Metab 2007, 28:563-578.

22. Aleyasin H, Rousseaux MW, Marcogliese PC, Hewitt SJ, Irrcher I, Joselin AP, Parsanejad M, Kim RH, Rizzu P, Callaghan SM, Slack RS, Mak TW, Park DS: DJ-1 protects the nigrostriatal axis from the neurotoxin MPTP by modulation of the AKT pathway. Proc Natl Acad Sci USA 2010, 107:3186-3191.

23. Miyazaki S, Yanagida T, Nunome K, Ishikawa S, Inden M, Kitamura Y, Nakagawa S, Taira T, Hirota K, Niwa M, Iguchi-Ariga SMM, Ariga H: DJ-1binding compounds prevent oxidative stress-induced cell death and movement defect in Parkinson's disease model rats. J Neurochem 2008, 105:2418-2434.

24. Yanagida T, Kitamura Y, Yamane K, Takahashi K, Takata K, Yanagisawa D, Yasui H, Taniguchi T, Taira T, Honda T, Ariga H: Protection against oxidative stress-induced neurodegeneration by a modulator for DJ-1, the wild-type of familial Parkinson's disease-linked PARK7. J Pharmacol Sci 2009, 109:463-468.

25. Yamane K, Kitamura Y, Yanagida T, Takata K, Yanagisawa D, Taniguchi T, Taira T, Ariga H: Oxidative neurodegeneration is prevented by UCP0045037, an allosteric modulator for the reduced form of DJ-1, a wild-type of familial Parkinson's disease-linked PARK7. Int J Mol Sci 2009, 10:4789-804

26. Honbou K, Suzuki NN, Horiuchi M, Niki T, Taira T, Ariga H, Inagaki F: The crystal structure of DJ-1, a protein related to male fertility and Parkinson's disease. J Biol Chem 2003, 278:31380-31384.

27. Wilson MA, Collins JL, Hod Y, Ringe D, Petsko GA: The 1.1-A resolution crystal structure of DJ-1, the protein mutated in autosomal recessive early onset Parkinson's disease. Proc Natl Acad Sci USA 2003, 100:9256-9261.

28. Glinka Y, Gassen M, Youdim MB: Mechanism of 6-hydroxydopamine neurotoxicity. J Neural Transm 1997, 50(Suppl):55-66.

29. Zecca L, Youdim MB, Riederer P, Connor JR, Crichton RR: Iron, brain ageing and neurodegenerative disorders. Nat Rev Neurosci 2004, 5:863-873.

30. Inden M, Kitamura Y, Takeuchi H, Yanagida T, Takata K, Kobayashi Y, Taniguchi T, Yoshimoto K, Kaneko M, Okuma Y, Taira T, Ariga H, Shimohama S: Neurodegeneration of mouse nigrostriatal dopaminergic system induced by repeated oral administration of rotenone is prevented by 4-phenylbutyrate, a chemical chaperone. J Neurochem 2007, 101:1491-1504

31. Inden M, Kitamura Y, Abe M, Tamaki A, Takata K, Taniguchi T: Parkinsonian rotenone mouse model: Reevaluation of long-term administration of rotenone in C57BL/6 mice. Biol Pharm Bull 2011, 34:92-96.

32. Clements CM, McNally RS, Conti BJ, Mak TW, Ting JP: DJ-1, a cancer- and Parkinson's disease-associated protein, stabilizes the antioxidant transcriptional master regulator Nrf2. Proc Natl Acad Sci USA 2006, 103:15091-1506.

33. Kim RH, Peters M, Jang Y, Shi W, Pintilie M, Fletcher GC, DeLuca C, Liepa J, Zhou L, Snow B, Binari RC, Manoukian AS, Bray MR, Liu FF, Tsao MS, 
Mak TW: DJ-1, a novel regulator of the tumor suppressor PTEN. Cancer Cell 2005, 7:263-273.

34. Kim YC, Kitaura H, Taira T, Iguchi-Ariga SMM, Ariga H: Oxidation of DJ-1dependent cell transformation through direct binding of DJ-1 to PTEN. Int J Oncol 2009, 35:1331-1341.

35. Mullett SJ, Hamilton RL, Hinkle DA: DJ-1 immunoreactivity in human brain astrocytes is dependent on infarct presence and infarct age. Neuropathology 2009, 29:125-131.

36. Sakurai M, Kawamura T, Nishimura H, Suzuki H, Tezuka F, Abe K: Induction of Parkinson disease-related proteins in motor neurons after transient spinal cord ischemia in rabbits. J Cereb Blood Flow Metab 2009, 29:752-758.

37. Sawada H, Kohno R, Kihara T, Izumi Y, Sakka N, Ibi M, Nakanishi M, Nakamizo T, Yamakawa K, Shibasaki H, Yamamoto N, Akaike A, Inden M, Kitamura Y, Taniguchi T, Shimohama S: Proteasome mediates dopaminergic neuronal degeneration, and its inhibition causes alphasynuclein inclusions. J Biol Chem 2004, 279:10710-10719.

38. Deumens R, Blokland A, Prickaerts J: Modeling Parkinson's disease in rats: an evaluation of 6-OHDA lesions of the nigrostriatal pathway. Exp Neurol 2002, 175:303-317.

39. Shimohama S, Sawada H, Kitamura Y, Taniguchi T: Disease model: Parkinson's disease. Trends Mol Med 2003, 9:360-365.

40. Deumens R, Blokland A, Prickaerts J: Modeling Parkinson's disease in rats: an evaluation of 6-OHDA lesions of the nigrostriatal pathway. Exp Neurol 2002, 175:303-317.

41. Agrawal AK, Shukla S, Chaturvedi RK, Seth K, Srivastava N, Ahmad A, Seth PK: Olfactory ensheathing cell transplantation restores functional deficits in rat model of Parkinson's disease: a cotransplantation approach with fetal ventral mesencephalic cells. Neurobiol Dis 2004, 16:516-526.

42. Armentero MT, Fancellu R, Nappi G, Bramanti P, Blandini F: Prolonged blockade of NMDA or mGluR5 glutamate receptors reduces nigrostriatal degeneration while inducing selective metabolic changes in basal ganglia circuitry in a rodent model of Parkinson's disease. Neurobiol Dis 2006, 22:1-9.

43. Xu L, Sheng J, Tang Z, Wu X, Yu Y, Guo H, Shen Y, Zhou C, Paraoan L, Zhou J: Cystain $C$ prevents degeneration of rat nigral dopaminergic neurons: in vitro and in vivo studies. Neurobiol Dis 2005, 18:152-165.

44. Mura A, Mintz M, Feldon J: Behavioral and anatomical effects of longterm I-dihydrophenylanine (I-DOPA) administration in rats with unilateral lesions of nigrostriatal system. Exp Neurol 2002, 177:252-264.

doi:10.1186/1750-1326-6-48

Cite this article as: Kitamura et al:: Neuroprotective effect of a new DJ-1binding compound against neurodegeneration in Parkinson's disease and stroke model rats. Molecular Neurodegeneration 2011 6:48.

\section{Submit your next manuscript to BioMed Central and take full advantage of:}

- Convenient online submission

- Thorough peer review

- No space constraints or color figure charges

- Immediate publication on acceptance

- Inclusion in PubMed, CAS, Scopus and Google Scholar

- Research which is freely available for redistribution

Submit your manuscript at www.biomedcentral.com/submit
Biomed Central 